\title{
Molecular mechanisms of biological aging in intervertebral discs
}

DOI:

10.1002/jor.23195

\section{Document Version}

Accepted author manuscript

Link to publication record in Manchester Research Explorer

\section{Citation for published version (APA):}

Vo, N. V., Hartman, R. A., Patil, P. R., Risbud, M. V., Kletsas, D., latridis, J. C., Hoyland, J. A., Le Maitre, C. L., Sowa, G. A., \& Kang, J. D. (2016). Molecular mechanisms of biological aging in intervertebral discs. Journal of Orthopaedic Research. https://doi.org/10.1002/jor.23195

\section{Published in:}

Journal of Orthopaedic Research

\section{Citing this paper}

Please note that where the full-text provided on Manchester Research Explorer is the Author Accepted Manuscript or Proof version this may differ from the final Published version. If citing, it is advised that you check and use the publisher's definitive version.

\section{General rights}

Copyright and moral rights for the publications made accessible in the Research Explorer are retained by the authors and/or other copyright owners and it is a condition of accessing publications that users recognise and abide by the legal requirements associated with these rights.

\section{Takedown policy}

If you believe that this document breaches copyright please refer to the University of Manchester's Takedown Procedures [http://man.ac.uk/04Y6Bo] or contact uml.scholarlycommunications@manchester.ac.uk providing relevant details, so we can investigate your claim.

\section{OPEN ACCESS}




\section{Special Issue Perspectives}

\section{Molecular Mechanisms of Biological Aging in Intervertebral Discs ${ }^{\dagger}$}

Nam V. Vo ${ }^{1,2^{*}}$, Robert A. Hartman ${ }^{3}$, Prashanti R. Patil ${ }^{1,2}$, Makarand V. Risbud ${ }^{4}$, Dimitris Kletsas ${ }^{5}$, James C. Iatridis ${ }^{6}$, Judith A. Hoyland ${ }^{7}$, Christine L. Le Maitre ${ }^{8}$, Gwendolyn A. Sowa ${ }^{1,3}$, James D. Kang $^{1}$

${ }^{1}$ Department of Orthopaedic Surgery, ${ }^{2}$ Department of Pathology, ${ }^{3}$ Department of Physical Medicine and Rehabilitation, University of Pittsburgh School of Medicine, Pittsburgh, Pennsylvania, USA.

${ }^{4}$ Department of Orthopaedic Surgery, Sidney Kimmel Medical College, Thomas Jefferson University, Philadelphia, PA, USA.

${ }^{5}$ Laboratory of Cell Proliferation and Ageing, Institute of Biosciences and Applications, National Centre for Scientific Research "Demokritos", Athens, Greece.

${ }^{6}$ Leni \& Peter W May Department of Orthopaedics, Icahn School of Medicine at Mount Sinai, New York, NY 10029, USA

${ }^{7}$ Centre for Tissue Injury and Repair, Faculty of Medical and Human Sciences, University of Manchester M13 9PT and NIHR Manchester Musculoskeletal Biomedical Research Unit, Manchester Academic Health Science Centre, Manchester, UK

${ }^{8}$ Musculoskeletal and Regenerative Medicine Research Group, Biomolecular Sciences Research Centre, Sheffield Hallam University, Sheffield, S1 1WB, UK

\section{*Corresponding author}

Nam V. Vo

Ferguson Laboratory for Orthopaedic Research, Department of Orthopaedic Surgery, University of Pittsburgh, 200 Lothrop Street, E1644 Biomedical Science Tower, Pittsburgh, PA 15261,USA

Tel: (412) 648-1092

Fax: (412) 383-5307

E-mail address: von@upmc.edu

Running title: Intervertebral disc aging

Key words: intervertebral disc, aging, oxidative damage, inflammation, cellular senescence, DNA repair

${ }^{\dagger}$ This article has been accepted for publication and undergone full peer review but has not been through the copyediting, typesetting, pagination and proofreading process, which may lead to differences between this version and the Version of Record. Please cite this article as doi: [10.1002/jor.23195]

Received 16 October 2015; Revised 30 December 2015; Accepted 3 February 2016 Journal of Orthopaedic Research This article is protected by copyright. All rights reserved DOI 10.1002/jor.23195

This article is protected by copyright. All rights reserved 


\begin{abstract}
Advanced age is the greatest risk factor for the majority of human ailments, including spine-related chronic disability and back pain, which stem from age-associated intervertebral disc degeneration (IDD). Given the rapid global rise in the aging population, understanding the biology of intervertebral disc aging in order to develop effective therapeutic interventions to combat the adverse effects of aging on disc health is now imperative. Fortunately, recent advances in aging research have begun to shed light on the basic biological process of aging. Here we review some of these insights and organize the complex process of disc aging into three different phases to guide research efforts to understand the biology of disc aging. The objective of this review is to provide an overview of the current knowledge and the recent progress made to elucidate specific molecular mechanisms underlying disc aging. In particular, studies over the last few years have uncovered cellular senescence and genomic instability as important drivers of disc aging. Supporting evidence comes from DNA repair-deficient animal models that show increased disc cellular senescence and accelerated disc aging. Additionally, stressinduced senescent cells have now been well documented to secrete catabolic factors, which can negatively impact the physiology of neighboring cells and ECM. These along with other molecular drivers of aging are reviewed in depth to shed crucial insights into the underlying mechanisms of agerelated disc degeneration. We also highlight molecular targets for novel therapies and emerging candidate therapeutics that may mitigate age-associated IDD. This article is protected by copyright. All rights reserved
\end{abstract}

This article is protected by copyright. All rights reserved 


\section{LIST OF ABBREVIATIONS}

AF: Annulus Fibrosus

ADAMTS: A Disintegrin And Metalloproteinase with Thrombospondin Motifs

AGES: Advanced Glycation End products

CEP: Cartilaginous Endplate

ECM: Extracellular Matrix

GAG: Glycosaminoglycan

IDD: Intervertebral Disc Degeneration

MMP: Matrix Metalloproteinase

MRI: Magnetic Resonance Imaging

NP: Nucleus Pulposus

ROS: Radical Oxygen Species

SA- $\beta$ gal: Senescence Associated Beta Galactosidase

SASP: Senescence Associated Secretory Phenotype

SIPS: Stress-induced Premature Senescence

SLRP: Small Leucine-rich Repeat family of Proteoglycans 


\section{INTRODUCTION}

Life expectancy has dramatically increased over the past century largely due to advances in medicine, control of infectious diseases, and improved nutrition. There were an estimated 0.5 billion people 65 years and older worldwide in 2010, and this number is projected reach a staggering 1.5 billion by $2050^{1}$. Emerging within the older population are numerous age-associated chronic diseases, including heart disease, cancer, and diabetes, which are the leading causes of death in developing countries ${ }^{2}$. Low back pain, which also increases with age, is the leading cause of physical disability ${ }^{3,4}$. Age-associated chronic diseases, including those of the musculoskeletal system, impose the greatest burden on global health presently and in the future.

One of the largest age-dependent chronic disorders is degeneration of the joints, resulting in enormous socioeconomic and health impacts. Intervertebral disc degeneration (IDD) and osteoarthritis and are the most common underlying causes of joint-related chronic disability and debilitating pain in the older adults $^{5-7}$. Unfortunately, decreased mobility is a validated predictor of loss of independence and mortality in the elderly ${ }^{8,9}$. Preserving healthy joints, particularly intervertebral discs in the spine, is vital for maintaining mobility in old age ${ }^{10}$. Individuals over 60 years old are more likely to suffer from pain stemming from IDD. As such, there is now great impetus to understand healthy disc aging in order to preserve mobility and fitness in the elderly population.

Organismal aging results from time-dependent accumulation of molecular and cellular damage that leads to impaired tissue homeostasis and eventual physiological and functional decline. Numerous types of damage are implicated in driving aging: accumulation of damaged proteins, mitochondrial damage and dysfunction, telomere shortening, DNA damage, attrition of quality control mechanisms (autophagy, DNA repair, etc.), and the loss of tissue-specific progenitor cells and tissue regenerative 
capacity ${ }^{11-14}$. The consequences of these different types of damage have recently been categorized into key aging hallmarks: genomic instability, telomere attrition, epigenetic alterations, loss of proteostasis, deregulated nutrient-sensing, mitochondrial dysfunction, cellular senescence, stem cell exhaustion, and altered intercellular communication ${ }^{15}$. Remarkably little is known about the contribution of these aging hallmarks to disc degeneration.

The purpose of this perspective is to provide an overview of disc aging characteristics and to organize the biochemical cascade of disc aging into three phases: (1) accumulation of damage to biomolecules, (2) aberrant cellular response to damage, and (3) loss of biologic structure and function. This perspective will focus particularly on cell senescence, inflammation, and oxidative damage as underlying mechanisms driving disc aging. Other important hallmarks of aging that have not been explored in the disc will be also highlighted in order to stimulate research that identifies potential causes and therapies for age-associated IDD.

\section{AGING CHARACTERISTICS OF INTERVERTEBRAL DISCS}

A. Disc anatomy and composition. Intervertebral discs are polyaxial cartilaginous joints that function primarily to provide support and flexibility to the otherwise rigid spine ${ }^{16}$. Situated between two adjacent vertebrae, discs consist of an outer, fibrous annulus fibrosus (AF) that circumferentially encloses a central, gelatinous nucleus pulposus (NP). Discs are constrained within and connected to adjacent vertebral bodies by superior and inferior cartilaginous end plates (CEP). The AF is composed of highly organized lamellae of predominantly type I collagen fibrils with alternating fiber angles of approximately $30^{\circ}$. AF functions mainly to bear circumferential stresses required to restrain NP swelling and tensile forces generated during bending or twisting. Conversely, the NP contains loose 
randomly organized networks of collagen type II and elastin fibers that encase proteoglycan aggregates. NP functions mainly to counteract and distribute compressive loads with large swelling pressures ${ }^{17}$. Discs consist mostly of extracellular matrix (ECM) sparsely populated by cells that are fibrochondrocytic in AF and chondrocyte-like and notochordal in NP. Discs are predominantly avascular, aneural tissues that exchange nutrients and metabolites primarily by diffusion to and from micro-vessels in the CEP and outer $\mathrm{AF}^{18}$. The restricted transport and low cellularity of the discs limit repair and make the disc particularly susceptible to injury and the aging-associated accumulation of tissue damage.

B. Features of disc aging. Intervertebral discs appear to undergo age-related degenerative changes earlier in life than other tissues ${ }^{19,20}$. Based on studies of humans and different animal models (Table 1), these age-related changes include increased number and size of tissue fissures, the presence of granular debris, and neovascularization from the outer aspect of the annulus inwards ${ }^{19}$. The NP becomes more fibrous as its proteoglycan content and hydration diminish with age, leading to fissures and progressive loss of NP size and pressurization and overall disc height ${ }^{21,22}$. Age-related accumulation of oxidized matrix proteins transforms the clear, gelatinous NP in youth to yellow, fibrous tissue in older individuals due to deposition of a brown 'age pigment' known as lipofusin, which originates from the slow peroxidation of lipids ${ }^{23}$ (Fig.1). Ossification and thinning of the CEP, microfractures in the adjacent subchondral bone, bone sclerosis, and drastic reduction in the number of vascular channels in the CEP are also found with increasing age ${ }^{24}$. Reduced CEP vascular flow might contribute to a further decreased in nutrient supply to the disc, accumulation of cellular waste products, and an increasingly acidic environment $(\mathrm{pH}$ 6.3-6.6) that together with other stress factors can negatively impact cell function $^{25}$. As such, elucidating disc aging-induced mechanisms will provide new opportunities for ameliorating age-related IDD. 
C. Distinguishing disc aging from disc degeneration. Disc aging can be distinguished from disc degeneration by several defining characteristics. First, disc degeneration refers to the structural and functional failure of the disc as a result of aberrant, pathological cellular and ECM changes ${ }^{26}$. Disc degeneration may be caused by genetic predisposition, injury, aging, and environmental factors such as smoking, or any combination thereof ${ }^{27-33}$. Unlike disc aging, disc degeneration is not exclusive to the older population, i.e., disc degeneration can be present in a younger person due to injury or faulty genetics $^{32-34}$. Conversely, disc aging is systemic and occurs in all spinal discs of all older individuals. In other words, a degenerated disc, but never an aged disc, can be found among the other young healthy discs and body organs in a young individual. However, the specific differences between an aged disc and a degenerated disc have not been clearly defined as both appear to share a number of similar changes ${ }^{19,20}$. Importantly, future work to identify the features common to aging and degeneration that are most pathologic to disc function will be critical in guiding novel treatments.

D. Impact on disc aging by the surrounding spinal structures. Because aging is systemic, agerelated changes in spinal structures can greatly impact disc health (Fig. 2). Osteoporosis and osteopenia are commonly observed in the aging spine, predisposing it to vertebral compression fractures ${ }^{35}$ and correlating with increased $\mathrm{IDD}^{36}$. Moreover, age-dependent endplate thinning and fracture create abnormal stress distributions and injury propagation to the adjacent disc, which increases the risk of $\mathrm{IDD}^{34,37}{ }^{38-40}$. Modic changes in the vertebral body and/or endplate identified by MRI have been associated with aging along with loss of disc height and signal intensity ${ }^{41}$. Vertebral endplate sclerosis is predicted to reduce bulk fluid movement in to and out of the disc, which could limit ancillary nutrient transport ${ }^{42,43} 44$. Together with reduced endplate pore density and size seen with aging, these changes could significantly impact disc nutrient supply and thus disc cell survival ${ }^{18}$. Age-related facet cartilage erosion can impose abnormal load on disc, altering local mechanobiological responses ${ }^{45}$. Aging of the posterior and anterior spinal ligaments, important dynamic stabilizers of the spine, alters This article is protected by copyright. All rights reserved 
their material properties (increased stiffness) which conceivably could also influence mechanical strain and stability of the discs ${ }^{35,46}$. Finally, age-driven changes in the spinal muscle, e.g., fatty deposit or infiltration, could also affect the overall stability of the spine and hence the biology of the disc ${ }^{47}$. In summary, disc aging is a complex systemic process that is intimately modulated by the interactions among the different aging spinal structures (Fig. 2).

\section{BIOCHEMICAL CASCADE OF INTERVERTEBRAL DISC AGING}

The biochemical process of disc aging can be organized into three distinct phases (Fig. 3A). First, there is damage to biomolecules such as DNA and proteins that results from exposure to inflammatory and oxidative stress. Second, aberrant cellular responses to damage exacerbates tissue damage when the responses become dysregulated. Third, accumulated damage leads to loss of biologic structure and function of disc tissue, as discussed in details below. Aging of the other spinal structures (Fig. 2) probably follows this same biochemical cascade.

A. Phase I of Biochemical Cascade of Disc Aging: Biomolecular Damage. A solid body of research supports time-dependent accumulation of stochastic damage to biological macromolecules as a driver of aging $^{48}$. Well documented in aged tissue are damaged proteins and genetic materials which lead to genomic instability, epigenetic alterations, and loss of proteostasis. Proteostasis refers to protein homeostasis regulated by a dynamic equilibrium of protein synthesis and degradation. ECM damage resulted from loss of proteostasis during the course of age-related IDD has been extensively documented. The role of DNA damage in disc aging has also been recently reported. However, epigenetic alterations in disc aging have not yet been explored. 
Damage and Perturbation of ECM Integrity in Aged Disc. Accumulation of molecular damage in the ECM of the aging disc has been well recognized (Fig. 4A) and reviewed ${ }^{49}$. Disc proteoglycan aggregates, consisting primarily of aggrecan core protein, link protein, and hyaluronan encased within the collagenous fiber network, provide the osmotic properties that create swelling pressure necessary to counteract compressive loading. In the aged disc the majority of the aggrecan exists in a nonaggregated form and contains decreased glycosaminoglycan (GAG) chain length, which is thought to be derived from proteolytic damage ${ }^{49}$. Link protein levels decrease with age ${ }^{50}$ while total disc hyaluronan levels increase with age, possibly as a response to its own proteolysis ${ }^{51}$. Versican is another major hyaluronan-binding proteoglycan in disc tissue which undergoes extensive degradative damage with aging ${ }^{52}$. The resulting non-aggregating proteoglycans may not have the same functional ability as that of intact aggregates, as their size, charge density, spatial rigidity and matrix interactions are diminished ${ }^{49,51,53,54}$.

The disc also contains the small leucine-rich repeat family of proteoglycans (SLRPs), which are characterized by their interaction with collagen fibers. Biglycan and decorin, the dermatan sulfate proteoglycans which interact with collagen type VI and type I/II, respectively, lose their GAG content with age due to proteolytic damage ${ }^{55}$. The keratin sulfate-containing fibromodulin and lumicans are two other disc collagen fibril-associated SLRPs. Whereas fibromodulin abundance decreases with age and exists mostly in non-glycated form in adult discs, lumican increases in aged discs and exists as a glycoprotein throughout life ${ }^{49} 56$. Since dermatan sulfate and keratin sulfate mediate intermolecular interaction, their age-related alterations most likely affects disc matrix structure. Age-related changes in other disc matrix constituents, e.g., elastin, fibronectin, have also been documented with unclear consequences on disc matrix organization and cell structure and function ${ }^{49} 57$. 
Disc tissue contains three broad categories of fibrillar, fibril-associated, and pericellular collagens whose relative abundance changes with age. The disc collagen network consists predominantly of Type I and II fibrillar collagen which accounts for approximately $80 \%$ of the total disc collagen. Type VI pericellular collagen accounts for $10-20 \%$ of the disc collagen ${ }^{49}$. Age-associated changes in disc collagen structure include proteolytic damage in fibrillar collagen as a result of dysregulated collagenase activity $^{58}$. Damaged fibrillary collagen weakens the mechanical strength of disc tissue and leads to the formation of non-enzymatic crosslinks between basic amino acids of collagen and reducing sugars $^{59}$. This results in advanced glycation end-products (AGEs) which elicit oxidative stress. AGEs are present throughout the disc and increase in abundance with age ${ }^{60}$ and may impair collagen fibril formation $^{61,62}$. In mice, oxidative stress was shown to increase loss of disc elasticity and alter the secondary and tertiary conformation of collagen molecules, which increases their susceptibility to cleavage by MMPs ${ }^{63}$. Hence age-related ECM molecular alterations can result in a decline in the structural integrity and biomechanical function of the disc.

DNA Damage in Aged Disc. Besides ECM damage, aged discs also exhibit cellular damage. In particular, damaged DNA, unlike damaged proteins or other macromolecules that generally can be degraded and replaced by new synthesis, is especially harmful and requires repair in order to maintain normal cellular function. Each cell in an organism is subjected to tens of thousands of DNA lesions each day due to the inherent chemical instability of DNA structure, metabolic byproducts, and environmental mutagens and genotoxins ${ }^{11}$. Despite elaborate repair mechanisms, cells still amass DNA damage over time. Inherited defects in genome maintenance mechanisms invariably lead to a variety of diseases characterized by accelerated aging of one or more organ systems ${ }^{12}$. For example, deficiency in humans of certain genes involved in repair of DNA damage, such as ERCC1-XPF, leads to dramatic progeroid, or accelerated aging syndrome ${ }^{64}$. Indeed, DNA repair-deficient $E r c c 1^{-/ \Delta}$ mice 
exhibit premature onset of key disc aging features, including loss of matrix proteoglycan, reduced disc height, and increased cellular senescence ${ }^{28,65}$ (Table 1). DNA damage as a driver of disc aging is further supported by exposure studies of human and mice to genotoxic stress, including ionizing radiation and tobacco smoking, which in mice dramatically accelerated disc degenerative changes ${ }^{66,67}$ 68

Stressors Driving Disc Biomolecular Damage. Exogenous and endogenous stressors causing molecular damage in aging discs are thought to be predominantly oxidative and inflammatory in nature (Fig. $3 \mathrm{~A})^{65,69}$. Evidence of oxidative damage in aged disc include accumulation advanced glycation end products (AGEs), e.g., pentosidine and carboxymethyl-lysine, produced by nonenzymatic glucosylation and oxidation of proteins and lipids ${ }^{60} 70$. Pentosidine, which cross-links collagen molecules, might play an important role in increased collagen stiffness and fragility to weaken cartilage biomechanics with old age ${ }^{59,60,71}$. Redox proteomic analysis also revealed oxidative post-translational modifications, e.g., protein carbonylation, in disc matrix isolated from aging mice; this change was associated with protein fragmentation and aggregation and increased disc stiffness ${ }^{63}$.

The source of reactive oxygen species (ROS) driving oxidative damage includes free radicals generated from radiation, by-products of oxidative phosphorylation, cellular response to chronic inflammatory stress exposure, and decreased synthesis of ROS-scavenging enzymes ${ }^{72}$. Although residing in a low oxygen tension environment, resident disc cells, especially AF cells, are capable of oxidative phosphorylation which can generate ROS. In addition, aged discs acquire fissures and associated neovascularization which exposure the otherwise hypoxic resident cells to higher oxygen tension and thus oxidative stress ${ }^{73}$. Increased ROS contribute to aging changes in cells and tissues by damaging proteins, lipids, and DNA. One key marker of protein oxidation is nitrotyrosine that is formed by the reaction of protein tyrosine residues with peroxynitrite $\left(\mathrm{ONOO}^{-}\right)^{74}$. Peroxynitrite, formed by rapid This article is protected by copyright. All rights reserved 
reaction of nitric oxide (NO) with oxygen radical superoxide $\left(\mathrm{O}_{2}{ }^{-}\right)$, is a potent cytotoxic damaging nitrating and oxidizing agent.

Intriguingly, hyperosmolality is recently demonstrated as a non-classical inducer of DNA damage. Hyperosmolality induces DNA double strand breaks, which activate the ATM-p53-p21WAF1 axis leading to the hypophosphorylation of the pRb protein and cell cycle arrest in the $G_{1}$ phase of the cell cycle $^{75}$. NP cells are continuously exposed to hyperosmolality, up to $500 \mathrm{mOsm} / \mathrm{kg} \mathrm{H}_{2} \mathrm{O}$ in vivo as compared with $<300 \mathrm{mOsm} / \mathrm{kg} \mathrm{H}_{2} \mathrm{O}$ in the majority of the other tissues ${ }^{76}$. Increased osmolality in NP cells was found to provoke chromatin changes and DNA damage ${ }^{75}$. It is still unclear what level of hyperosmolality is needed to overwhelm NP cell DNA repair capacity to introduce DNA damage.

Abnormal mechanical loading represents another major potential stressors that can promote disc tissue damage. Cohort analyses point to associations between long-term physical loading and loss of spinal mobility and disc height ${ }^{77}$, and other age-associated IDD $^{78,79} 80$. In animal studies, rats with imposed upright stance for up to 11 months showed increased disc senescence, presumably due to altered magnitude and mode of disc loading ${ }^{81}$. Modest age-related IDD features in rat discs were observed following compressive overloading for eight weeks ${ }^{82,83}$. However, more studies are needed to establish role of abnormal mechanical loading in promoting disc degenerative changes, with or without age associations.

Last but not least, nutritional stress can also promote perturbation in disc tissue. The avascular nature of disc tissue results in an environment of low oxygen and glucose concentrations and high lactate concentration $^{84,85}$. Despite low physiologic concentrations of oxygen ${ }^{85}$ and glucose ${ }^{84}$ and high concentrations of lactate $(>10 \mathrm{x} \text { plasma concentrations })^{86}$, which acidify the inner disc environment, 
disc cells can remain viable and functional in this hostile environment. Yet low nutrition and $\mathrm{pH}$ are also the very factors that reduce the disc's resilience to additional nutritional and environmental stresses $^{87,88}$; this is because disc nutrient supply barely hovers above the cellular requirements in the $\mathrm{NP}^{89}$. This precarious balance may expose disc cells to nutritional deprivation due age-related processes. For instance, disc cell death is initiated if glucose concentrations drop below critical thresholds $(<0.5 \mathrm{mM}){ }^{90}$. Acidic conditions $(\mathrm{pH}<6.7)$ can also lower cell viability ${ }^{91}$. Low $\mathrm{O}_{2}$ and $\mathrm{pH}$ conditions have been shown to diminish proteoglycan and collagen synthesis ${ }^{86,92}$.

\section{B. Phase II of Biochemical Cascade of Disc Aging: Aberrant Responses to Damage. In an attempt} to repair damage, cellular responses may become dysregulated over time, which exacerbate cellular and ECM damage. Aberrant molecular signaling, abnormal changes in cell fate, dysregulated nutrient sensing, and mitochondrial dysfunction all have been reported in non-disc tissues ${ }^{15}$. However, only abnormal alterations in cell fate (e.g., cellular senescence) and dysregulated signaling (e.g., NF- $\kappa \mathrm{B}$ pathway) have been reported recently in studies on disc aging. These two areas of research are discussed below.

Cell Functional and Phenotypic Changes in Disc Aging. AF and NP differ in their developmental origin, with AF developing from the mesenchyme and the NP from the notochord. The cells in the outer AF are elongated and fibroblast-like, whereas the inner AF and NP are populated by more spheroidal, chondrocyte-like cells. While cell types in the outer AF appear to change little during lifetime, NP cell subpopulations undergo a substantial change whereby clusters of large vacuolated notochordal cells in young NP are replaced by smaller chondrocyte-like cells in older $\mathrm{NP}^{93}$. Cell density decreased from 0 to 16 years, and no significant variation occurred thereafter in human lumbar discs ${ }^{94}$. Cell density in normal, mature disc is approximately $4 \times 10^{6}$ cells $/ \mathrm{cm}^{3}$ in the NP and $9 \times 10^{6}$ This article is protected by copyright. All rights reserved 
cells $/ \mathrm{cm}^{3}$ in the $\mathrm{AF}^{49}$. During aging disc cells undergo a number of phenotypic changes, including a switch from an anabolic to a catabolic phenotype ${ }^{95-99}$. Cells isolated from aged discs exhibit reduced collagen and proteoglycan matrix anabolism ${ }^{95-97,100}$. Moreover, found in aged discs are elevated levels matrix proteoglycan degradative products and certain matrix metalloproteinases (MMPs), including MMP-3 and ADAMTS-5 $5^{101} 98,99$ 102,103. The pro-inflammatory cytokine TNF- $\alpha$ is also shown to be more highly expressed in older adult discs than young adult discs ${ }^{104}$. These observations suggest imbalanced matrix homeostatic phenotype as a consequence of age-associated changes in disc cells. Additionally, other cell phenotypic changes such as elevated necrosis, apoptosis, and senescence have been reported ${ }^{105,106}$ (Fig. 4B). These phenotypic and functional changes are likely consequences of aberrant cellular responses to accumulated biomolecular damage in disc tissue. Such changes also likely contribute to loss of functional cells, leading to age-related depletion of disc matrix proteoglycan, tissue dehydration, and altered load distribution that may increase risk of injury ${ }^{87,107}$.

The Role of Cellular Senescence in Disc Aging. Cell senescence, originally described as a process that limits cell proliferation ${ }^{108,109}$, is an important mechanism for preventing the proliferation of potential cancer cells. This type of senescence is known as replicative senescence, characterized by cessation of cell proliferation due to critical shortening of telomere length after successive replicative cell cycles. Another type of cellular senescence was discovered relatively recently, which was termed, "stressinduced premature senescence (SIPS)". SIPS is formed as a result of accumulate genomic and mitochondrial DNA damage. SIPS cells also acquire a senescence associated secretory phenotype (SASP), a unique feature in which they secrete high amounts of numerous inflammatory cytokines and matrix proteinases, which can have profound catabolic effects on neighboring cells and $\mathrm{ECM}^{110,111}$. Because senescent cells accumulate in various tissues and organs with aging ${ }^{12}$, SASP is currently believed to disrupt tissue structure and function and promote aging ${ }^{113}$. This theory is supported by a seminal study demonstrating that clearance of senescent cells delays aging-associated disorders ${ }^{114}$. This article is protected by copyright. All rights reserved 
An increased number of senescent cells were observed in both aged and degenerated discs ${ }^{105,115-118}$, as measured by increased expression of senescent markers, including senescence-associated $\beta$ galactosidase (SA- $\beta$ gal), p16 ${ }^{\mathrm{INK} 4 \mathrm{~A}}$, and decreased telomere length. Thus, cellular senescence is a potential driver of both disc degeneration and disc aging, possibly through the SASP mechanism that promotes pathologic disc matrix catabolism. Evidence supporting this idea originally came from a study showing a positive correlation between the senescent marker $\mathrm{p} 16^{\mathrm{INK} 4 \mathrm{~A}}$ and matrix proteases expression (MMP-13 and ADAMTs-5) in human disc tissue, implicating senescent disc cells as a source of these catabolic enzymes ${ }^{105}$. In vitro cell culture studies using $\mathrm{H}_{2} \mathrm{O}_{2}$ to simulate oxidative DNA damage that induces SIPS also revealed an altered, catabolic phenotype ${ }^{119}$. These $\mathrm{H}_{2} \mathrm{O}_{2}$-induced senescent disc cells exhibited SASP, as characterized by their secretion of high levels of MMPs and pro-inflammatory cytokines. These senescent disc cells also showed growth arrest and perturbed matrix homeostasis, i.e., reduced matrix synthesis capacity (anabolism) and increased matrix degradation (catabolism) ${ }^{120}$. However, to determine the causative role of cellular senescence in driving disc aging, genetic and pharmacological in vivo strategies are needed to study the effects of ablation of senescent cells on age-associated IDD.

Possible causes of disc cellular senescence. DNA damage is the underlying cause of cellular senescence, but how cells become senescent in disc tissue is not fully understood. Current evidence supports the existence of both replicative senescence and SIPS in discs. Telomere length shortening, a marker of replicative senescence, is observed in aged and degenerated human disc tissue, as is increased $\mathrm{p} 16^{\text {Ink4a }}$ immunopositivity, a marker of SIPS ${ }^{105,121}$. Elevated cellular senescence was observed in discs of DNA repair-deficient $\operatorname{Erccl}^{-/ \Delta}$ mice $^{28}$ as well as in genotoxin-exposed mice ${ }^{66,67}$, suggesting that DNA damage is a key driver of disc cellular senescence. Other potential sources of oxidative DNA damage include oxidative stress induced by inflammation and high glucose-induced oxidative This article is protected by copyright. All rights reserved 
stress, e.g., in diabetes ${ }^{122}$. IL-1, a predominant cytokine implicated in the pathogenesis of disc degeneration $^{123,124}$, has been suggested to promote SIPS in NP cells. Indeed, spontaneous age-related IDD with associated senescent phenotype is seen in an IL-1Ra knockout mouse model ${ }^{125}$. Finally, activation of $\mathrm{WNT} / \beta$-catenin signaling was also reported to promote cellular senescence in rat disc cells $^{126}$, but it is unclear in disc tissue how this signaling is influenced by oxidative or inflammatory stress that drives senescence. In summary, disc senescence phenotype appears to be specific aberrant cell response to DNA damage which can cause further tissue perturbation and damage during the course of disc aging (Fig. 3A).

Aberrant Molecular Signaling in Disc Aging. Biomolecular damage, e.g., DNA damage, can initiate aberrant signaling cascade, which then, if left unchecked, acts to cause further molecular damage. It is now well known that in addition to environmental factors and behavior traits, genetics greatly influences lifespan. Most longevity genes identified starting from the early 1980s in various models (worms, fruit flies, mice, monkeys...etc.) implicate one of three major signaling pathways in cells: insulin/IGF-1, sirtuins, or mTOR ${ }^{13,127,128}$. These three pathways regulate a variety of cellular processes, including cell growth, cell proliferation and survival, protein synthesis, and transcription mechanisms. The roles of these signaling pathways in disc aging, however, have not been explored although it is known that Insulin-like growth factor-1 (IGF-1) induces disc anabolic activity ${ }^{129}$ while SIRT1 is expressed by human NP cells and acts to suppress NP cell matrix metabolism and proliferation ${ }^{130}$. However, signaling other than these three pathways have been reported to influence age-related IDD, including NF- $\kappa \mathrm{B}, \mathrm{MAPK}$, and HIF-1 $\alpha$ signaling which are known to be involved in stress responses and SIPS, which are discussed below.

$N F k B$ signaling in age-related disc degeneration. $\mathrm{NF}-\kappa \mathrm{B}$ signaling is central to the cellular response to inflammation, stress and damage. $\mathrm{NF}-\kappa \mathrm{B}$ is comprised of a family of structurally related 
transcription factors, which in mammals consists of five protein subunits, RelA or p65, c-Rel, RelB, p50 and p52. NF- $\kappa \mathrm{B}$ exists as a homodimer or a heterodimer, with the p50-p65 heterodimer being the most common form which controls the expression of the majority of NF- $\kappa$ B-regulated genes ${ }^{131}$. Chronic activation of NF- $\mathrm{BB}$ has been linked to tissue aging and many age-related degenerative diseases, including musculoskeletal disorders such as muscular dystrophy, osteoarthritis, and osteoporosis $^{132,133134}$.

$\mathrm{NF}-\kappa \mathrm{B}$ is also implicated age-associated $\mathrm{IDD}^{135}$. In disc tissue, $\mathrm{NF}-\kappa \mathrm{B}$ activity was shown to correlate with accumulated oxidative stress and increase with age and degeneration ${ }^{70}$. Systemic inhibition of $\mathrm{NF}-\kappa \mathrm{B}$ activity by pharmacologic and genetic means has been shown to ameliorate age-associated IDD in a mouse model of accelerated aging ${ }^{136}$. Most other studies focus on the role of NF- $\kappa \mathrm{B}$ in mediating degenerative and inflammatory disc disease. Increased NF- $\kappa$ B activity is found in degenerative discs ${ }^{135}$. Compared to asymptomatic discs, symptomatic discs have higher levels of pro-inflammatory cytokines that are considered typical NF- $\kappa$ B target genes, e.g. TNF- $\alpha$, IL-1 $\beta$, IL-6 and IL-8 ${ }^{104,123,124,137}$. Together, these findings support the role of dysregulated NF- $\kappa \mathrm{B}$ chronic activation in promoting IDD and age-related IDD.

MAPK signaling in disc biology and disc aging. Mitogen-Activated Protein Kinases (MAPKs) are a family of signal transduction pathways, allowing the cells to respond to multiple extracellular inputs, such as hormones, growth factors, inflammatory cytokines, and environmental stresses such as ionizing radiation or osmotic stress ${ }^{138,139}$. In mammals, these diverse signals activate at least three major subfamilies of MAPKs, the extracellular signal-regulated kinases (ERK), c-Jun NH2- terminal kinases $(\mathrm{JNKs})$, and p38 isoforms (p38MAPKs) ${ }^{140,141}$. Activation of MEK/ERK and JNK are involved in the induction of cellular senescence ${ }^{142}{ }^{143}$. On the other hand, p38 MAPK activation is a marker of 
senescence and plays a vital role in establishing SASP which probably affects local tissue homeostasis ${ }^{144}$. Consistent with in vitro data, up-regulated p38 MAPK expression has been reported in senescent AF cells isolated by laser capture microdissection ${ }^{145}$.

Multiple components of the catabolic machinery (e.g. MMPs, ADAMTSs, COX-2, PGE2, iNOS, etc) are regulated by MAPK family members. Many of these catabolic genes are also regulated by NF- $\kappa \mathrm{B}$ signaling, highlighting the cross-talks between the components of MAPK and NF- $\mathrm{BB}$ pathways ${ }^{135}$. In disc tissue, the major pro-inflammatory cytokines, i.e., IL-1 $\beta$ and TNF- $\alpha$, activate ERK and/or p38 and consequently catabolic molecules such as ADAMTs-4, MMP-3 or syndecan-4 ${ }^{146-149}$. Inhibition of MAPK activation by specific synthetic compounds or naturally occurring molecules such as glucosamine prevent these processes, indicating that MAPK regulation may represent a promising tool to mitigate disc degeneration and aging ${ }^{147,150}$.

Increased disc cell proliferation and formation of cell clusters is a characteristic feature of disc degeneration ${ }^{151}$. This is thought to be partly due the over-expression of growth factors and their receptors $^{152}$. Growth factors such as PDGF, IGF-I or bFGF stimulate cell proliferation via ERK activation $^{153,154}$, indicating an additional role of MAPK in disc degeneration. Conversely, hyperosmotic conditions inhibit ERK, arrest cell cycle in the $\mathrm{G}_{2} / \mathrm{M}$ phase via p38 MAPK activation and restrain the mitogenic effect of growth factors, indicating that the reduced osmolality prevailing in the degenerated disc may boost cell proliferation ${ }^{155}$. Whether disc aging involves these same signaling pathways as they are related to cell proliferation and clustering awaits further investigation. 
HIF-1 $\alpha$ signaling in disc biology and disc aging. For any meaningful discussion of aging of disc at the molecular level, it is important to consider the unique niche and physiology of the cells of NP and inner AF. NP resides in a hypoxic and hyperosmotic environment ${ }^{156,157}$ to which they have adapted a novel hypoxia signaling governed by the activities of the transcription factors hypoxiainducible factor- $1 \alpha$ and $-2 \alpha$ (HIF-1/2). Unlike other cell types in which HIF-1 $\alpha$ protein stability and activity are enhanced under hypoxia and abolished under normoxia, NP cells constitutively express both HIF- $1 \alpha$ and HIF- $2 \alpha$, even under normoxic conditions ${ }^{158}$. In fact, NP cells are either partially or wholly refractory to propyl-hydroxylases (PHD)-dependent degradation ${ }^{159,160}$. Similarly, Factor Inhibiting HIF-1 (FIH-1) does not control HIF-1 $\alpha$ transcriptional activity in NP cells ${ }^{161}$ as typically seen in other cell types. The constitutive HIF-1 expression has important metabolic consequences for NP cells which are obligate glycolytic and rely very little on aerobic respiration even when oxygen is abundant ${ }^{162}$. In addition to this metabolic adaptation, HIFs promote survival and function of NP cells through upregulation of crucial genes including, aggrecan ${ }^{162}$, galectin- $3^{163}, \beta-1,3$-glucuronyltransferase $1^{164}$, and VEGF-A ${ }^{165}$. In fact HIF-1 is indispensable for NP cell survival as demonstrated by conditional knockout of HIF-1 $\alpha$ in mouse notochord by Foxa2-Cre which results in smaller, nonvacuolated cells in the NP at E15.5 and massive apoptotic cell death in the NP at birth ${ }^{166}$. Thus, the important role of HIF signaling in physiological adaptation and function of NP cells suggests that its dysregulation may contribute to cellular aging and degeneration.

The role of HIF signaling in organismal aging was recently elucidated. Dysregulated increase in HIF$1 \alpha$ activities due to age-dependent decline of nuclear $\mathrm{NAD}^{+}$was found to interfere with the coordination between nuclear and mitochondrial activities, resulting in mitochondrial dysfunction and accelerated aging $^{167}$. However, other studies suggested a role of HIF-1 in suppressing cellular senescence ${ }^{168,169}$. These conflicting results require further investigation in order to elucidate how 
dysregulated HIF signaling contributes to disc aging, given that robust and stabilized HIF-1 $\alpha$ expression is vital for NP cell survival and function ${ }^{162}$. One possible mechanism involves cross-talk between HIF and NF-kB pathways under pathological conditions ${ }^{170,171}$. TNF- $\alpha$ controls expression of

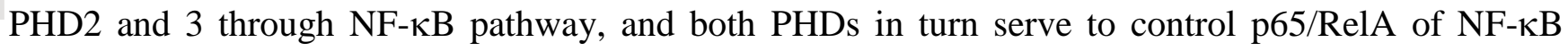
transactivation. Importantly, PHDs partially control a broader TNF-dependent inflammatory response by promoting expression of several cytokines and chemokines ${ }^{170,171}$. More studies are needed to detangle the complex interaction and possible dysregulation between HIF and NF-kB pathways that might predispose disc tissue to accelerated aging.

\section{Phase III of Biochemical Cascade of Disc Aging: Loss of Biologic Structure and Function.}

Loss of disc biologic structure and function (phase III) is an end consequence of time-dependent accumulation of damage resulting from biomolecular changes (phase I) and associated aberrant signaling (phase II) (Fig. 3A). Damage-induced apoptosis, cellular senescence, and pathologic alterations in matrix metabolism all likely contribute to the loss of disc functional cells, stem cell pool $^{172-175}$, and ECM structural integrity (Fig. 4). These changes are expected to alter ECM-cell communication and eventually the normal physiology and biomechanical function of the disc (Fig. $3 \mathrm{~A})$.

Loss of disc ECM integrity and altered cell mechanobiology. Loss of disc matrix proteoglycans decreases the negatively charged ionic environment, reducing hyperosmotic loading ionic flux ${ }^{176}$. Loss of hydration alters fluid pressurization and fluid flows in the disc ${ }^{177}$. Age-related changes to the solid matrix, such as increased non-enzymatic collagen cross-linking ${ }^{59}{ }^{178}$, protein glycation ${ }^{179}$, or protein denaturation ${ }^{180}$ can increase structural stiffness ${ }^{180}$ and alter disc strains ${ }^{181}$. Moreover, AF damage 
increases with age ${ }^{182}$, which can alter tensile stiffness and annular local strains ${ }^{183} 184$. These changes perturb the cellular microenvironment and compromise normal disc function.

Cell clustering and interactions with the pericellular matrix also appear to change with age ${ }^{185}$, which suggest altered cellular mechanical properties ${ }^{186}$. Indeed, disc cells from young and middle-aged bovine respond differently to the same compression regimes, with older cells showing diminished capacity for matrix repair ${ }^{187}$. Similarly, AF cells from mature and aged pigs subjected to loading exhibit differences in anabolic and catabolic gene expression, further suggesting changes to cells or mechanotransduction with aging ${ }^{188}$. Cells isolated from injury-induced degenerative discs also demonstrated differences in response to mechanical loading ${ }^{189}$, but the effect of physiologic aging was not evaluated.

Mechanical features of aging discs: loss of physiological biomechanics. The complex structure of the disc allows multiaxial motion while maintaining stability ${ }^{190,191}$. NP and AF interact to support compressive loading and facilitate segmental motion. Compression increases swelling pressure in the $\mathrm{NP}^{192} 193$ which is constrained by the surrounding, distensible AF and the adjacent CEPs ${ }^{194}$. In distraction, the AF limits vertebral body motion ${ }^{181}$. The organized, concentric lamellae of the AF resist torsion through circumferential tensile stress in its collagen and elastin fibers ${ }^{195-197}$. The physiological function of the spine thus depends on these integrated interactions among the different disc regions ${ }^{198,199}$. A number of mechanical features specific to aging have been identified within the disc. Hydration levels within the NP decrease in aging, which, along with GAG depletion ${ }^{200}$, reduces swelling pressure in the $\mathrm{NP}^{192} 201$ and increases the shear modulus of NP with age ${ }^{202}$. On the other hand, hydration in the AF remains relatively unchanged with aging ${ }^{192}$, and annular tensile properties change only modestly with aging ${ }^{183,203}$. The net result of these age-related changes, is a loss of 
elasticity and increased stiffness ${ }^{63} 180$, which overlaps with mechanical changes in non-age related disc degeneration.

\section{POTENTIAL THERAPIES TO DELAY AGE-ASSOCIATED IDD}

The events within disc aging cascade present potential therapeutic targets for treating or delaying agerelated IDD (Fig. 3B). In theory, treatments that reduce free radical production may ameliorate macromolecular damage. Indeed, accelerated aging $\operatorname{Erccl}^{-/ \Delta}$ mice treated with systemic administration of XJB-5-131, a mitochondria-targeted ROS scavenger, resulted in improved disc GAG content and proteoglycan synthesis $^{204}$. This demonstrates that mitochondria-derived ROS drives aging-related IDD and that radical scavengers may play a promising role in slowing disc aging. Anti-oxidants such as curcumin and resveratrol have also been reported to be therapeutic for treating IDD, as have a number of other anti-inflammatory agents such as NSAIDS and IL-1 $\mathrm{Ra}^{205-210}$. Whether these same agents are therapeutic against age-related IDD await further research.

Minimizing the aberrant damage responses that exacerbate tissue damage is another strategy for treating age-related IDD. One promising candidate is the NF- $\kappa \mathrm{B}$ pathway whose chronic activation has been closely linked to age-related diseases. Previous studies demonstrated that blocking NF- $\kappa \mathrm{B}$ activity pharmacologically and genetically in the $\operatorname{Erccl}^{-/ \Delta}$ rodent model of accelerated aging delayed the onset of age-dependent disc proteoglycan loss and other degenerative changes ${ }^{136,211}$. Moreover, intra-discal injection of 'naked' NF- $\kappa \mathrm{B}$ decoy oligonucleotides proved effective in partially restoring disc height in an animal model of $\mathrm{IDD}^{212}$, indicating that dysregulated activation of NF- $\kappa \mathrm{B}$ is involved in disc matrix loss. 
Other potential strategies involve the use of protein-, gene-, and cell- based therapy to counter agerelated changes to the matrix and cells, respectively ${ }^{213-215}$ (Fig. 3B). The goal of most gene therapy approaches is to replace loss of disc ECM via increased matrix synthesis or to inhibit catabolic factors that degrade the matrix ${ }^{216}$. Cell-based therapy frequently aims to restore loss of functional disc cells with possible anti-inflammatory effects ${ }^{217,218}$. These interventions aim at either preventing damage, ensuring optimal cellular response to damage, or restoring tissue loss associated with aging. Indeed, such strategies exist and have been extensively investigated in the context of disc degeneration. To be effective, however, therapeutic interventions need to target the early phases of the disc aging cascade prior to the occurrence of functional failure.

\section{CONCLUSIONS AND PERSPECTIVES}

A large number of studies dating back to the early 1950s describe various age-related disc degenerative changes. However, the molecular mechanisms which initiate and mediate disc aging are still poorly understood. Recent advances in the aging research field are beginning to reveal important insights into the mechanisms of organismal aging. Based on these insights, we proposed to organize the complex multi-step process of disc aging into three distinct phases to guide future research: (1) biomolecular damage, (2) aberrant damage responses, and (3) loss of biologic structure and function. While genomic instability, cellular senescence, and dysregulated NF- $\kappa \mathrm{B}$ signaling have been recently uncovered in disc aging, research is still lagging to elucidate the roles of other important aging hallmarks such as mitochondrial dysfunction, stem cell exhaustion, altered intercellular communication, and epigenetic alterations in disc tissue. The unique disc biological niche, i.e., mechanically loaded, nutrient-poor, acidic and hypoxic environment, offers an excellent opportunity to discover novel disc aging mechanisms that might be distinct from those driving aging in other tissues. Importantly, disc aging is a systemic process that does not occur in isolation and is likely influenced by 
the aging processes of neighboring spinal structures (Fig. 2), circulating factors, and remote body tissues and organs. Hence, aging research of the whole spine, not just the disc, is an important, immediate future direction. The broad, multi-tiered approach is necessary to provide the basic information needed for the development of effective therapies and interventions to delay the onset of age-related spinal disorders. This is imperative given aging is a big risk factor for IDD-associated chronic pain and disability, the prevalence of which will undoubtedly be amplified with the growing aging population.

\section{ACKNOWLEDGEMENTS}

This work was made possible in part by the Public Health Service grant R01 AG044376-01 (NVV), R01-AR055655, R01-AR064733 (MVR) from the National Institute of Health and UPMC Rehabilitation Institute Pilot Grant 2015 (RAH). 
Figure 1. Gross features of the aged mammalian discs. Axial sections of young and aged lumbar discs of 3 month- vs. 24 month-old mice (A, B), 3 week- vs. 3 year-old pigs (C, D) ${ }^{219}$, and 16 year- vs. 55 year-old humans (E,F, courtesy of Dr. Ian Stokes), are shown. Old discs exhibit an overall loss of hydration, loss of demarcation between the AF and NP boundary, and tissue discoloration (old disc more yellowish). Average lumbar disc cross-sectional diameters are approximately 2-3mm for mice, 24-30 mm for pigs, and 45-55mm for humans ${ }^{220}$.

Figure 2. Gross features of the aging spine. Young and aged lumbar spines are visually compared to illustrate the wide range of tissues and processes involved in aging of the spine. Muscle atrophy and fatty infiltration is evident at L1-2 in the aged spine. 25Similarly, a window into L3 depicts reduced vascularity and fewer capillaries reaching the endplate. Foraminal stenosis is shown at L2-3 (arrow), L3-4, and L4-5, and facet hypertrophy is evident at L3-4 (arrow) and L4-5. An annular lesion is present in the posterior portion of the L3-4 disc. Disc degeneration with evident loss of disc height and prominent anterior osteophytes occur at L4-5. Ligamentous thickening is indicated in the interspinous and supraspinous ligament; thickening of the ligamentum flavum occurs with aging but is not observable in the sagittal view. Finally, facet cartilage arthritis is revealed on the inferior facet of L5.

Figure 3. Proposed biochemical cascade in disc aging process and potential therapeutic targets. (A) With aging, there is time-dependent accumulation of biomolecular damage (Phase I), most importantly, DNA damage, in the disc due to exogenous and endogenous factors. Cellular responses to accumulated damage over time become dysregulated (Phase II) leading to more damage and eventual loss of disc biologic structure and function (Phase III). This results in degenerative changes observed in aged discs. * Observed in other tissues but not yet investigated in disc tissue. (B) Potential therapeutic targets to delay or ameliorate age-related degeneration. Oxidative and inflammatory stress can be reduced with anti-oxidants and anti-inflammatory drugs. Reducing chronic activation of NF- $\kappa \mathrm{B}$ signaling by pharmacologic intervention may be efficacious in delaying age-related degeneration. Moreover, removal of senescent cells or blocking formation of SASP could potentially mitigate disc matrix catabolism. Finally, protein-, gene- and cell-based therapy could also conceivably delay or help restore age-related loss of disc matrix and functional cells.

Figure 4. Molecular and cellular features of the aging disc. Young and aged extracellular matrix (A) and cells (B) are schematically compared to summarize important changes that occur during disc aging. Panel A, young matrix is rich in elastin (green, coiled fiber), aggregated aggrecan (dark blue, bottle-brush aggregate), and collagen fibers (banded fibers). Aged matrix shows loss of elastin, increased collagen and collagen crosslinking, fragmented aggregan, diminished GAG quality, reduced aggregan aggregates, increased accumulation of advanced glycation end-products (AGEs) along with lower hydration $^{49}$. Panel B, young AF cells are elongated fibrochondrocytes and NP cells are a mixture 
of large, clustering, notochordal cells and smaller, chondrocyte-like cells. Aged cells show reduced cellularity, loss of notchordal cells, and incidence of senescence, apoptosis, and necrosis.

This article is protected by copyright. All rights reserved 


\section{REFERENCES}

1. World Population Prospects The 2015 Revision . at <http://esa.un.org/unpd/wpp/Publications/Files/Key_Findings_WPP_2015.pdf>

2. Christensen, K., Doblhammer, G., Rau, R. \& Vaupel, J. W. Ageing populations: the challenges ahead. Lancet 374, 1196-208 (2009).

3. The Burden of Musculoskeletal Diseases in the United States. (American Academy of Orthopaedic Surgeons, 2008). at <http://www.boneandjointburden.org/docs/The Burden of Musculoskeletal Diseases in the United States (BMUS) 1st Edition (2008).pdf $>$

4. Derby R, Lee SH, Kim BJ. Discography. In: Slipman CW, Derby R, Simeone FA, M. \& er TG, E. Interventional Spine: an algorithmic approach. Elsevier 291-302. (2008).

5. Prevalence of knee osteoarthritis in the United States: arthritis data from the Third National Health and Nutrition Examination Survey 1991-1994. at <http://www.jrheum.org/content/33/11/2271.full.pdf>

6. Goldring, M. B. \& Goldring, S. R. Osteoarthritis. J. Cell. Physiol. 213, 626-34 (2007).

7. Aging Theories of Primary Osteoarthritis: From Epidemiology to Molecular Biology. at <http://online.liebertpub.com/doi/pdf/10.1089/1549168041552964>

8. Cesari, M. et al. Oxidative Damage, Platelet Activation, and Inflammation to Predict Mobility Disability and Mortality in Older Persons: Results From the Health Aging and Body Composition Study. Journals Gerontol. Ser. A Biol. Sci. Med. Sci. 67A, 671-676 (2012).

9. Hirvensalo, M., Rantanen, T. \& Heikkinen, E. Mobility difficulties and physical activity as predictors of mortality and loss of independence in the community-living older population. $J$. Am. Geriatr. Soc. 48, 493-8 (2000).

10. Morone, N. E. et al. Impact of chronic musculoskeletal pathology on older adults: a study of differences between knee OA and low back pain. Pain Med. 10, 693-701

11. Niedernhofer, L. J. \& Robbins, P. D. Signaling mechanisms involved in the response to genotoxic stress and regulating lifespan. Int. J. Biochem. Cell Biol. 40, 176-80 (2008). 
12. Hasty, P., Campisi, J., Hoeijmakers, J., van Steeg, H. \& Vijg, J. Aging and genome maintenance: lessons from the mouse? Science 299, 1355-9 (2003).

13. Guarente, L. Mitochondria--a nexus for aging, calorie restriction, and sirtuins? Cell 132, 171-6 (2008).

14. Finkel, T. \& Holbrook, N. J. Oxidants, oxidative stress and the biology of ageing. Nature 408, 239-47 (2000).

15. López-Otín, C., Blasco, M. A., Partridge, L., Serrano, M. \& Kroemer, G. The hallmarks of aging. Cell 153, 1194-217 (2013).

16. Shapiro, I. M., Vresilovic, E. J. \& Risbud, M. V. Is the spinal motion segment a diarthrodial polyaxial joint: what a nice nucleus like you doing in a joint like this? Bone 50, 771-6 (2012).

17. Roughley P. J,Alini M, A. J. The role of proteoglycans in aging, degeneration and repair of the intervertebral disc. Biochem. Soc. Trans. 30, 869-74 (2002).

18. Urban, J. P. G., Smith, S. \& Fairbank, J. C. T. Nutrition of the intervertebral disc. Spine (Phila. Pa. 1976). 29, 2700-9 (2004).

19. Boos, N. et al. Classification of age-related changes in lumbar intervertebral discs: 2002 Volvo Award in basic science. Spine (Phila. Pa. 1976). 27, 2631-44 (2002).

20. Miller, J. A., Schmatz, C. \& Schultz, A. B. Lumbar disc degeneration: correlation with age, sex, and spine level in 600 autopsy specimens. Spine (Phila. Pa. 1976). 13, 173-8 (1988).

21. Kumaresan, S., Yoganandan, N., Pintar, F. A., Macias, M. \& Cusick, J. F. Morphology of young and old cervical spine intervertebral disc tissues. Biomed. Sci. Instrum. 36, 141-6 (2000).

22. Prescher, A. Anatomy and pathology of the aging spine. Eur. J. Radiol. 27, 181-95 (1998).

23. Hormel, S. E. \& Eyre, D. R. Collagen in the ageing human intervertebral disc: an increase in covalently bound fluorophores and chromophores. Biochim. Biophys. Acta 1078, 243-50 (1991).

24. Edelson, J. G. \& Nathan, H. Stages in the natural history of the vertebral end-plates. Spine (Phila. Pa. 1976). 13, 21-6 (1988).

25. Bibby, S. R. S., Jones, D. A., Ripley, R. M. \& Urban, J. P. G. Metabolism of the intervertebral 
disc: effects of low levels of oxygen, glucose, and $\mathrm{pH}$ on rates of energy metabolism of bovine nucleus pulposus cells. Spine (Phila. Pa. 1976). 30, 487-96 (2005).

26. Adams, M. A. \& Roughley, P. J. What is intervertebral disc degeneration, and what causes it? Spine (Phila. Pa. 1976). 31, 2151-61 (2006).

27. Nasto, L. A. et al. Investigating the role of DNA damage in tobacco smoking-induced spine degeneration. Spine J. 14, 416-23 (2014).

28. Vo, N. et al. Accelerated aging of intervertebral discs in a mouse model of progeria. J. Orthop. Res. 28, 1600-7 (2010).

29. Chan, D., Song, Y., Sham, P. \& Cheung, K. M. C. Genetics of disc degeneration. Eur. Spine J. 15 Suppl 3, S317-25 (2006).

30. Moon, C. H. et al. Part 2: Quantitative proton T2 and sodium magnetic resonance imaging to assess intervertebral disc degeneration in a rabbit model. Spine (Phila. Pa. 1976). 37, E1113-9 (2012).

31. Samartzis, D., Karppinen, J., Chan, D., Luk, K. D. K. \& Cheung, K. M. C. The association of lumbar intervertebral disc degeneration on magnetic resonance imaging with body mass index in overweight and obese adults: a population-based study. Arthritis Rheum. 64, 1488-96 (2012).

32. Livshits, G. et al. Lumbar disc degeneration and genetic factors are the main risk factors for low back pain in women: the UK Twin Spine Study. Ann. Rheum. Dis. 70, 1740-5 (2011).

33. Sambrook, P. N., MacGregor, A. J. \& Spector, T. D. Genetic influences on cervical and lumbar disc degeneration: a magnetic resonance imaging study in twins. Arthritis Rheum. 42, 366-72 (1999).

34. Haschtmann, D., Stoyanov, J. V, Gédet, P. \& Ferguson, S. J. Vertebral endplate trauma induces disc cell apoptosis and promotes organ degeneration in vitro. Eur. Spine J. 17, 289-99 (2008).

35. Ferguson, S. J. \& Steffen, T. Biomechanics of the aging spine. Eur. Spine J. 12 Suppl 2, S97S103 (2003).

36. Harada, A., Okuizumi, H., Miyagi, N. \& Genda, E. Correlation between bone mineral density and intervertebral disc degeneration. Spine (Phila. Pa. 1976). 23, 857-61; discussion 862 (1998).

37. Dudli, S., Haschtmann, D. \& Ferguson, S. J. Fracture of the vertebral endplates, but not

This article is protected by copyright. All rights reserved 
equienergetic impact load, promotes disc degeneration in vitro. J. Orthop. Res. 30, 809-816 (2012).

38. Setton, L. A. \& Chen, J. Mechanobiology of the intervertebral disc and relevance to disc degeneration. J. Bone Joint Surg. Am. 88 Suppl 2, 52-57 (2006).

39. Holm, S., Holm, A. K., Ekström, L., Karladani, A. \& Hansson, T. Experimental disc degeneration due to endplate injury. J. Spinal Disord. Tech. (2004). doi:10.1097/00024720200402000-00012

40. Dolan, P. et al. Intervertebral disc decompression following endplate damage: implications for disc degeneration depend on spinal level and age. Spine (Phila. Pa. 1976). 38, 1473-81 (2013).

41. Määttä, J. H., Wadge, S., MacGregor, A., Karppinen, J. \& Williams, F. M. K. ISSLS Prize Winner: Vertebral Endplate (Modic) Change is an Independent Risk Factor for Episodes of Severe and Disabling Low Back Pain. Spine (Phila. Pa. 1976). 40, 1187-93 (2015).

42. Gullbrand, S. E. et al. Low rate loading-induced convection enhances net transport into the intervertebral disc in vivo. 15, 1028-1033 (2015).

43. Galbusera F, Mietsch A, Schmidt H, Wilke HJ, N.-W. C. Effect of intervertebral disc degeneration on cell viability: a numerical investigation. Comput Methods Biomech Biomed Engin. 16, 328-337 (2013).

44. Ayotte, D. C., Ito, K., Perren, S. M. \& Tepic, S. Direction-dependent constriction flow in a poroelastic solid: the intervertebral disc valve. J. Biomech. Eng. 122, 587-93 (2000).

45. Benneker, L. M., Heini, P. F., Alini, M., Anderson, S. E. \& Ito, K. 2004 Young Investigator Award Winner: vertebral endplate marrow contact channel occlusions and intervertebral disc degeneration. Spine (Phila. Pa. 1976). 30, 167-73 (2005).

46. Sairyo, K. et al. Lumbar ligamentum flavum hypertrophy is due to accumulation of inflammation-related scar tissue. Spine (Phila. Pa. 1976). 32, E340-7 (2007).

47. D'hooge, R. et al. Increased intramuscular fatty infiltration without differences in lumbar muscle cross-sectional area during remission of unilateral recurrent low back pain. Man. Ther. 17, 5848 (2012).

48. Campisi, J. \& Vijg, J. Does Damage to DNA and Other Macromolecules Play a Role in Aging? If So, How? Journals Gerontol. Ser. A Biol. Sci. Med. Sci. 64A, 175-178 (2009). 
49. Roughley, P. J. Biology of intervertebral disc aging and degeneration: involvement of the extracellular matrix. Spine (Phila. Pa. 1976). 29, 2691-9 (2004).

50. Tengblad, A., Pearce, R. H. \& Grimmer, B. J. Demonstration of link protein in proteoglycan aggregates from human intervertebral disc. Biochem. J. 222, 85-92 (1984).

51. Scott, J. E., Bosworth, T. R., Cribb, A. M. \& Taylor, J. R. The chemical morphology of agerelated changes in human intervertebral disc glycosaminoglycans from cervical, thoracic and lumbar nucleus pulposus and annulus fibrosus. J. Anat. 184 ( Pt 1, 73-82 (1994).

52. Sztrolovics, R. et al. The characterization of versican and its message in human articular cartilage and intervertebral disc. J. Orthop. Res. 20, 257-266 (2002).

53. Buckwalter, J. A. Aging and degeneration of the human intervertebral disc. Spine (Phila. Pa. 1976). 20, 1307-14 (1995).

54. Adams, P., Eyre, D. R. \& Muir, H. Biochemical aspects of development and ageing of human lumbar intervertebral discs. Rheumatol. Rehabil. 16, 22-9 (1977).

55. Roughley, P. J. et al. Non-proteoglycan forms of biglycan increase with age in human articular cartilage. Biochem. J. 295 ( Pt 2, 421-6 (1993).

56. Sztrolovics, R., Alini, M., Mort, J. S. \& Roughley, P. J. Age-related changes in fibromodulin and lumican in human intervertebral discs. Spine (Phila. Pa. 1976). 24, 1765-71 (1999).

57. Silberberg, F., Meier-Ruge, W. \& Odermatt, B. Age-related changes in fibronectin in annulus fibrosus of the sand rat (Psammomys obesus). Exp Cell Biol 57, 233-237 (1989).

58. Hollander, A. Enhanced denaturation of the a1(II) chains of type-II collagen in normal adult human intervertebral discs compared with femoral articular cartilage. Journal of Orthopaedic Research (1996). at <http://repository.liv.ac.uk/1774860/>

59. Pokharna, H. K. \& Phillips, F. M. Collagen crosslinks in human lumbar intervertebral disc aging. Spine (Phila. Pa. 1976). 23, 1645-8 (1998).

60. Sivan, S. S. et al. Age-related accumulation of pentosidine in aggrecan and collagen from normal and degenerate human intervertebral discs. Biochem. J. 399, 29-35 (2006).

61. Gautieri, A., Redaelli, A., Buehler, M. J. \& Vesentini, S. Age- and diabetes-related nonenzymatic crosslinks in collagen fibrils: candidate amino acids involved in Advanced

This article is protected by copyright. All rights reserved 
Glycation End-products. Matrix Biol. 34, 89-95 (2014).

62. Verzijl, N. et al. Crosslinking by advanced glycation end products increases the stiffness of the collagen network in human articular cartilage: A possible mechanism through which age is a risk factor for osteoarthritis. Arthritis Rheum. 46, 114-123 (2002).

63. Scharf, B. et al. Age-related carbonylation of fibrocartilage structural proteins drives tissue degenerative modification. Chem. Biol. 20, 922-34 (2013).

64. Niedernhofer, L. J. et al. A new progeroid syndrome reveals that genotoxic stress suppresses the somatotroph axis. Nature 444, 1038-43 (2006).

65. Vo, N. et al. An overview of underlying causes and animal models for the study of age-related degenerative disorders of the spine and synovial joints. J. Orthop. Res. 31, 831-7 (2013).

66. Nasto, L. A. et al. Genotoxic stress accelerates age-associated degenerative changes in intervertebral discs. Mech. Ageing Dev. 134, 35-42

67. Wang, D. et al. Spine degeneration in a murine model of chronic human tobacco smokers. Osteoarthritis Cartilage 20, 896-905 (2012).

68. Mellor, F. E. \& Breen, A. C. Ionizing radiation exposure and the development of intervertebral disc degeneration--no case to answer. Spine J. 13, 224-6 (2013).

69. Risbud, M. V \& Shapiro, I. M. Role of cytokines in intervertebral disc degeneration: pain and disc content. Nat. Rev. Rheumatol. 10, 44-56 (2014).

70. Nerlich, A. G. et al. Immunomorphological analysis of RAGE receptor expression and NFkappaB activation in tissue samples from normal and degenerated intervertebral discs of various ages. Ann. N. Y. Acad. Sci. 1096, 239-48 (2007).

71. Bank, R. A., Bayliss, M. T., Lafeber, F. P., Maroudas, A. \& Tekoppele, J. M. Ageing and zonal variation in post-translational modification of collagen in normal human articular cartilage. The age-related increase in non-enzymatic glycation affects biomechanical properties of cartilage. Biochem. J. 330 ( Pt 1, 345-51 (1998).

72. Tiku, M. L., Liesch, J. B. \& Robertson, F. M. Production of hydrogen peroxide by rabbit articular chondrocytes. Enhancement by cytokines. J. Immunol. 145, 690-6 (1990).

73. Ali, R., Le Maitre, C. L., Richardson, S. M., Hoyland, J. A. \& Freemont, A. J. Connective tissue

This article is protected by copyright. All rights reserved 
growth factor expression in human intervertebral disc: implications for angiogenesis in intervertebral disc degeneration. Biotech. Histochem. 83, 239-45 (2008).

74. Reiter, C. D., Teng, R. J. \& Beckman, J. S. Superoxide reacts with nitric oxide to nitrate tyrosine at physiological pH via peroxynitrite. J. Biol. Chem. 275, 32460-6 (2000).

75. Mavrogonatou, E. \& Kletsas, D. High osmolality activates the G1 and G2 cell cycle checkpoints and affects the DNA integrity of nucleus pulposus intervertebral disc cells triggering an enhanced DNA repair response. DNA Repair (Amst). 8, 930-943 (2009).

76. Urban, J. P. The role of the physicochemical environment in determining disc cell behaviour. Biochem Soc Trans 30, 858-64 (2002).

77. Raty, H. P., Battie, M. C., Videman, T. \& Sarna, S. Lumbar mobility in former elite male weight-lifters, soccer players, long-distance runners and shooters. Clin. Biomech. 12, 325-330 (1997).

78. Videman, T. et al. Magnetic resonance imaging findings and their relationships in the thoracic and lumbar spine. Insights into the etiopathogenesis of spinal degeneration. Spine (Phila. Pa. 1976). 20, 928-935 (1995).

79. Videman, T., Levälahti, E. \& Battié, M. C. The effects of anthropometrics, lifting strength, and physical activities in disc degeneration. Spine (Phila. Pa. 1976). 32, 1406-1413 (2007).

80. Galbusera, F., Brayda-Bruno, M. \& Wilke, H. J. Is post-contrast MRI a valuable method for the study of the nutrition of the intervertebral disc? Journal of Biomechanics (2014). doi:10.1016/j.jbiomech.2014.06.039

81. Xing, Q.-J. et al. Leg amputation accelerates senescence of rat lumbar intervertebral discs. Spine (Phila. Pa. 1976). 35, E1253-E1261 (2010).

82. Wuertz, K. et al. In vivo remodeling of intervertebral discs in response to short- and long-term dynamic compression. J. Orthop. Res. 27, 1235-1242 (2009).

83. latridis, J. C., Godburn, K., Wuertz, K., Alini, M. \& Roughley, P. J. Region-dependent aggrecan degradation patterns in the rat intervertebral disc are affected by mechanical loading in vivo. Spine (Phila. Pa. 1976). 36, 203-209 (2011).

84. Holm, S., Maroudas, A., Urban, J. P., Selstam, G. \& Nachemson, A. Nutrition of the intervertebral disc: solute transport and metabolism. Connect. Tissue Res. 8, 101-119 (1981). 
85. Urban, J. P., Holm, S., Maroudas, A. \& Nachemson, A. Nutrition of the intervertebral disc: effect of fluid flow on solute transport. Clin. Orthop. Relat. Res. 296-302 (1982).

86. Ohshima, H. \& Urban, J. P. G. The effect of lactate and pH on proteoglycan. Spine (Phila. Pa. 1976). 17, 1079-82 (1992).

87. W, G., Q, Z., X, G. \& MD., B. Simulation of the progression of intervertebral disc degeneration due to decreased nutritional supply. Spine (Phila Pa 1976). 39, E1411-7 (2014).

88. Shirazi-Adl, A., Taheri, M. \& Urban, J. P. G. Analysis of cell viability in intervertebral disc: Effect of endplate permeability on cell population. J. Biomech. 43, 1330-1336 (2010).

89. Maroudas, A., Stockwell, R. A., Nachemson, A. \& Urban, J. Factors involved in the nutrition of the human lumbar intervertebral disc: cellularity and diffusion of glucose in vitro. J. Anat. 120, 113-30 (1975).

90. Bibby, S. R. S. \& Urban, J. P. G. Effect of nutrient deprivation on the viability of intervertebral disc cells. Eur. Spine J. 13, 695-701 (2004).

91. Bibby, S. R. S., Jones, D. a, Ripley, R. M. \& Urban, J. P. G. Metabolism of the intervertebral disc: effects of low levels of oxygen, glucose, and $\mathrm{pH}$ on rates of energy metabolism of bovine nucleus pulposus cells. Spine (Phila. Pa. 1976). 30, 487-96 (2005).

92. Ishihara, H. \& Urban, J. P. Effects of low oxygen concentrations and metabolic inhibitors on proteoglycan and protein synthesis rates in the intervertebral disc. J Orthop Res 17, 829-835 (1999).

93. Risbud, M. V \& Shapiro, I. M. Notochordal cells in the adult intervertebral disc: new perspective on an old question. Crit. Rev. Eukaryot. Gene Expr. 21, 29-41 (2011).

94. Liebscher, T., Haefeli, M., Wuertz, K., Nerlich, A. G. \& Boos, N. Age-related variation in cell density of human lumbar intervertebral disc. Spine (Phila. Pa. 1976). 36, 153-9 (2011).

95. Cole, T. C., Ghosh, P. \& Taylor, T. K. Variations of the proteoglycans of the canine intervertebral disc with ageing. Biochim. Biophys. Acta 880, 209-19 (1986).

96. Maeda, S. \& Kokubun, S. Changes with age in proteoglycan synthesis in cells cultured in vitro from the inner and outer rabbit annulus fibrosus. Responses to interleukin-1 and interleukin-1 receptor antagonist protein. Spine (Phila. Pa. 1976). 25, 166-9 (2000). 
97. Singh, K., Masuda, K., Thonar, E. J.-M. A., An, H. S. \& Cs-Szabo, G. Age-Related Changes in the Extracellular Matrix of Nucleus Pulposus and Anulus Fibrosus of Human Intervertebral Disc. Spine (Phila. Pa. 1976). 34, 10-16 (2009).

98. Pearce, R. H., Mathieson, J. M., Mort, J. S. \& Roughley, P. J. Effect of age on the abundance and fragmentation of link protein of the human intervertebral disc. J. Orthop. Res. 7, 861-7 (1989).

99. Sztrolovics, R., Alini, M., Roughley, P. J. \& Mort, J. S. Aggrecan degradation in human intervertebral disc and articular cartilage. Biochem. J. 326 ( Pt 1, 235-41 (1997).

100. Okuda, S. et al. Mechanisms of age-related decline in insulin-like growth factor-I dependent proteoglycan synthesis in rat intervertebral disc cells. Spine (Phila. Pa. 1976). 26, 2421-6 (2001).

101. Nerlich, A. G., Schleicher, E. D. \& Boos, N. 1997 Volvo Award winner in basic science studies. Immunohistologic markers for age-related changes of human lumbar intervertebral discs. Spine (Phila. Pa. 1976). 22, 2781-95 (1997).

102. Haidong Xu, Qiang Mei, Bin Xu, Gang Liu, J. Z. Expression of matrix metalloproteinases is positively related to the severity of disc degeneration and growing age in the East Asian lumbar disc herniation patients. Cell Biochem. Biophys. 70, 1219-25 (2014).

103. Zhao, C. Q. et al. ADAMTS-5 and intervertebral disc degeneration: The results of tissue immunohistochemistry and in vitro cell culture. J. Orthop. Res. 29, 718-725 (2011).

104. Bachmeier, B. E. et al. Analysis of tissue distribution of TNF-alpha, TNF-alpha-receptors, and the activating TNF-alpha-converting enzyme suggests activation of the TNF-alpha system in the aging intervertebral disc. Ann. N. Y. Acad. Sci. 1096, 44-54 (2007).

105. Le Maitre, C. L., Freemont, A. J. \& Hoyland, J. A. Accelerated cellular senescence in degenerate intervertebral discs: a possible role in the pathogenesis of intervertebral disc degeneration. Arthritis Res. Ther. 9, R45 (2007).

106. Zhao, C.-Q., Wang, L.-M., Jiang, L.-S. \& Dai, L.-Y. The cell biology of intervertebral disc aging and degeneration. Ageing Res. Rev. 6, 247-61 (2007).

107. Zhu, Q., Gao, X. \& Gu, W. Temporal changes of mechanical signals and extracellular composition in human intervertebral disc during degenerative progression. J. Biomech. 47, 3734-3743 (2014).

This article is protected by copyright. All rights reserved 
108. Hayflick, L. The limited in vitro lifetime of human diploid cell strains. Exp. Cell Res. 37, 614636 (1965).

109. van Deursen, J. M. The role of senescent cells in ageing. Nature 509, 439-46 (2014).

110. Acosta, J. C. et al. Chemokine signaling via the CXCR2 receptor reinforces senescence. Cell 133, 1006-18 (2008).

111. Coppé, J.-P. et al. Senescence-associated secretory phenotypes reveal cell-nonautonomous functions of oncogenic RAS and the p53 tumor suppressor. PLoS Biol. 6, 2853-68 (2008).

112. Campisi, J. Senescent cells, tumor suppression, and organismal aging: good citizens, bad neighbors. Cell 120, 513-22 (2005).

113. Rodier, F. et al. Persistent DNA damage signalling triggers senescence-associated inflammatory cytokine secretion. Nat. Cell Biol. 11, 973-9 (2009).

114. Baker, D. J. et al. Clearance of p16Ink4a-positive senescent cells delays ageing-associated disorders. Nature 479, 232-6 (2011).

115. Roberts, S., Evans, E. H., Kletsas, D., Jaffray, D. C. \& Eisenstein, S. M. Senescence in human intervertebral discs. Eur. Spine J. 15 Suppl 3, S312-6 (2006).

116. Gruber, H. E., Ingram, J. A., Davis, D. E. \& Hanley, E. N. Increased cell senescence is associated with decreased cell proliferation in vivo in the degenerating human annulus. Spine J. 9, 210-5 (2009).

117. Kim, K.-W., Chung, H.-N., Ha, K.-Y., Lee, J.-S. \& Kim, Y.-Y. Senescence mechanisms of nucleus pulposus chondrocytes in human intervertebral discs. Spine J. 9, 658-66 (2009).

118. Heathfield, S. K., Le Maitre, C. L. \& Hoyland, J. A. Caveolin-1 expression and stress-induced premature senescence in human intervertebral disc degeneration. Arthritis Res. Ther. 10, R87 (2008).

119. Dimozi, A., Mavrogonatou, E., Sklirou, A. \& Kletsas, D. Oxidative stress inhibits the proliferation, induces premature senescence and promotes a catabolic phenotype in human nucleus pulposus intervertebral disc cells. Eur. Cell. Mater. 30, 89-103 (2015).

120. Kevin Ngo. CHARACTERIZATION OF SENESCENT INTERVERTEBRAL DISC CELLS AND THEIR ROLE IN PERTURBATION OF MATRIX HOMEOSTASIS Master's Thesis,

This article is protected by copyright. All rights reserved 
University of Pittsburgh. (2015).

121. Tchkonia, T., Zhu, Y., van Deursen, J., Campisi, J. \& Kirkland, J. L. Cellular senescence and the senescent secretory phenotype: therapeutic opportunities. J. Clin. Invest. 123, 966-72 (2013).

122. Park, J.-S., Park, J.-B., Park, I.-J. \& Park, E.-Y. Accelerated premature stress-induced senescence of young annulus fibrosus cells of rats by high glucose-induced oxidative stress. Int Orthop. 38, 1311-20 (2014).

123. Phillips, K. L. E. et al. Potential roles of cytokines and chemokines in human intervertebral disc degeneration: interleukin-1 is a master regulator of catabolic processes. Osteoarthritis Cartilage 23, 1165-77 (2015).

124. Le Maitre, C. L., Freemont, A. J. \& Hoyland, J. A. The role of interleukin-1 in the pathogenesis of human intervertebral disc degeneration. Arthritis Res. Ther. 7, R732-45 (2005).

125. Phillips, K. L. E., Jordan-Mahy, N., Nicklin, M. J. H. \& Le Maitre, C. L. Interleukin-1 receptor antagonist deficient mice provide insights into pathogenesis of human intervertebral disc degeneration. Ann. Rheum. Dis. 72, 1860-7 (2013).

126. Hiyama, A. et al. Enhancement of intervertebral disc cell senescence by WNT/ $\beta$-catenin signaling-induced matrix metalloproteinase expression. Arthritis Rheum. 62, 3036-47 (2010).

127. Cuervo, A. M. Autophagy and aging: keeping that old broom working. Trends Genet. 24, 60412 (2008).

128. Pawlikowska, L. et al. Association of common genetic variation in the insulin/IGF1 signaling pathway with human longevity. Aging Cell 8, 460-72 (2009).

129. Huang, C.-Y., Travascio, F. \& Gu, W. Y. Quantitative analysis of exogenous IGF-1 administration of intervertebral disc through intradiscal injection. J. Biomech. 45, 1149-55 (2012).

130. Zhang, Z. et al. Expression of silent mating type information regulator 2 homolog 1 and its role in human intervertebral disc cell homeostasis. Arthritis Res. Ther. 13, R200 (2011).

131. Baeuerle, P. A. \& Henkel, T. Function and activation of NF-kappa B in the immune system. Annu. Rev. Immunol. 12, 141-79 (1994).

132. Acharyya, S. et al. Interplay of IKK/NF-kappaB signaling in macrophages and myofibers

This article is protected by copyright. All rights reserved 
promotes muscle degeneration in Duchenne muscular dystrophy. J. Clin. Invest. 117, 889-901 (2007).

133. Kim, H. J. et al. Antioxidant $\alpha$-lipoic acid inhibits osteoclast differentiation by reducing nuclear factor- $\kappa \mathrm{B}$ DNA binding and prevents in vivo bone resorption induced by receptor activator of nuclear factor- $\kappa \mathrm{B}$ ligand and tumor necrosis factor- $\alpha$. Free Radic. Biol. Med. 40, 1483-1493 (2006).

134. Adler, A. S. et al. Motif module map reveals enforcement of aging by continual NF-kappaB activity. Genes Dev. 21, 3244-57 (2007).

135. Wuertz, K., Vo, N., Kletsas, D. \& Boos, N. Inflammatory and catabolic signalling in intervertebral discs: the roles of NF-אB and MAP kinases. Eur. Cell. Mater. 23, 103-19; discussion 119-20 (2012).

136. Nasto, L. A. et al. ISSLS prize winner: inhibition of NF- $\kappa \mathrm{B}$ activity ameliorates age-associated disc degeneration in a mouse model of accelerated aging. Spine (Phila. Pa. 1976). 37, 1819-25 (2012).

137. Le Maitre, C., Hoyland, J. \& Freemont, A. J. Catabolic cytokine expression in degenerate and herniated human intervertebral discs: IL-1 $\beta$ and TNF $\alpha$ expression profile. Arthritis Res. Ther. 9, R77 (2007).

138. Huang, P., Han, J. \& Hui, L. MAPK signaling in inflammation-associated cancer development. Protein Cell 1, 218-26 (2010).

139. Kyriakis, J. M. \& Avruch, J. Mammalian MAPK signal transduction pathways activated by stress and inflammation: a 10-year update. Physiol. Rev. 92, 689-737 (2012).

140. Wagner, E. F. \& Nebreda, A. R. Signal integration by JNK and p38 MAPK pathways in cancer development. Nat. Rev. Cancer 9, 537-49 (2009).

141. Boutros, T., Chevet, E. \& Metrakos, P. Mitogen-activated protein (MAP) kinase/MAP kinase phosphatase regulation: roles in cell growth, death, and cancer. Pharmacol. Rev. 60, 261-310 (2008).

142. Lin, A. W. et al. Premature senescence involving p53 and p16 is activated in response to constitutive MEK/MAPK mitogenic signaling. Genes Dev. 12, 3008-19 (1998).

143. Maruyama, J., Naguro, I., Takeda, K. \& Ichijo, H. Stress-activated MAP kinase cascades in cellular senescence. Curr. Med. Chem. 16, 1229-35 (2009).

This article is protected by copyright. All rights reserved 
144. Freund, A., Patil, C. K. \& Campisi, J. p38MAPK is a novel DNA damage response-independent regulator of the senescence-associated secretory phenotype. EMBO J. 30, 1536-48 (2011).

145. Gruber, H. E., Hoelscher, G. L., Ingram, J. A., Zinchenko, N. \& Hanley, E. N. Senescent vs. non-senescent cells in the human annulus in vivo: cell harvest with laser capture microdissection and gene expression studies with microarray analysis. BMC Biotechnol. 10, 5 (2010).

146. Wang, X. et al. Tumor necrosis factor- $\alpha$ - and interleukin- $1 \beta$-dependent matrix metalloproteinase- 3 expression in nucleus pulposus cells requires cooperative signaling via syndecan 4 and mitogen-activated protein kinase-NF- $\kappa \mathrm{B}$ axis: implications in inflammatory disc disease. Am. J. Pathol. 184, 2560-72 (2014).

147. Mavrogonatou, E., Angelopoulou, M. T. \& Kletsas, D. The catabolic effect of TNF $\alpha$ on bovine nucleus pulposus intervertebral disc cells and the restraining role of glucosamine sulfate in the TNF $\alpha$-mediated up-regulation of MMP-3. J. Orthop. Res. 32, 1701-7 (2014).

148. Tian, Y. et al. Inflammatory cytokines associated with degenerative disc disease control aggrecanase-1 (ADAMTS-4) expression in nucleus pulposus cells through MAPK and NF-кB. Am. J. Pathol. 182, 2310-21 (2013).

149. Yang, W. et al. Interleukin-1 $\beta$ in intervertebral disk degeneration. Clin. Chim. Acta. 450, 262$272(2015)$.

150. Studer, R. K. et al. p38 MAPK inhibition modulates rabbit nucleus pulposus cell response to IL1. J. Orthop. Res. 26, 991-998 (2008).

151. Johnson, W. E., Eisenstein, S. M. \& Roberts, S. Cell cluster formation in degenerate lumbar intervertebral discs is associated with increased disc cell proliferation. Connect. Tissue Res. 42, 197-207 (2001).

152. Pratsinis, H. \& Kletsas, D. Growth Factors in Intervertebral Disc Homeostasis. Connect. Tissue Res. 49, 273-276 (2015).

153. Pratsinis, H., Constantinou, V., Pavlakis, K., Sapkas, G. \& Kletsas, D. Exogenous and autocrine growth factors stimulate human intervertebral disc cell proliferation via the ERK and Akt pathways. J. Orthop. Res. 30, 958-64 (2012).

154. Pratsinis, H. \& Kletsas, D. PDGF, bFGF and IGF-I stimulate the proliferation of intervertebral disc cells in vitro via the activation of the ERK and Akt signaling pathways. Eur. Spine J. 16, 1858-66 (2007).

This article is protected by copyright. All rights reserved 
155. Mavrogonatou, E. \& Kletsas, D. Effect of varying osmotic conditions on the response of bovine nucleus pulposus cells to growth factors and the activation of the ERK and Akt pathways. $J$ Orthop Res (2010). doi:10.1002/jor.21140

156. Risbud, M. V, Schipani, E. \& Shapiro, I. M. Hypoxic regulation of nucleus pulposus cell survival: from niche to notch. Am. J. Pathol. 176, 1577-83 (2010).

157. Johnson, Z. I., Shapiro, I. M. \& Risbud, M. V. Extracellular osmolarity regulates matrix homeostasis in the intervertebral disc and articular cartilage: evolving role of TonEBP. Matrix Biol. 40, 10-6 (2014).

158. Risbud, M. V et al. Nucleus pulposus cells express HIF-1 alpha under normoxic culture conditions: a metabolic adaptation to the intervertebral disc microenvironment. J. Cell. Biochem. 98, 152-9 (2006).

159. Fujita, N., Chiba, K., Shapiro, I. M. \& Risbud, M. V. HIF-1 $\alpha$ and HIF- $2 \alpha$ degradation is differentially regulated in nucleus pulposus cells of the intervertebral disc. J. Bone Miner. Res. 27, 401-12 (2012).

160. Fujita, N. et al. Expression of prolyl hydroxylases (PHDs) is selectively controlled by HIF-1 and HIF-2 proteins in nucleus pulposus cells of the intervertebral disc: distinct roles of PHD2 and PHD3 proteins in controlling HIF-1 $\alpha$ activity in hypoxia. J. Biol. Chem. 287, 16975-86 (2012).

161. Hirose, Y. et al. FIH-1-Mint3 axis does not control HIF-1 transcriptional activity in nucleus pulposus cells. J. Biol. Chem. 289, 20594-605 (2014).

162. Agrawal, A. et al. Normoxic stabilization of HIF-1alpha drives glycolytic metabolism and regulates aggrecan gene expression in nucleus pulposus cells of the rat intervertebral disk. Am. $J$. Physiol. Cell Physiol. 293, C621-31 (2007).

163. Zeng, Y., Danielson, K. G., Albert, T. J., Shapiro, I. M. \& Risbud, M. V. HIF-1 alpha is a regulator of galectin-3 expression in the intervertebral disc. J. Bone Miner. Res. 22, 1851-61 (2007).

164. Gogate, S. S., Nasser, R., Shapiro, I. M. \& Risbud, M. V. Hypoxic regulation of $\beta-1,3-$ glucuronyltransferase 1 expression in nucleus pulposus cells of the rat intervertebral disc: role of hypoxia-inducible factor proteins. Arthritis Rheum. 63, 1950-60 (2011).

165. Agrawal, A. et al. Cited2 modulates hypoxia-inducible factor-dependent expression of vascular endothelial growth factor in nucleus pulposus cells of the rat intervertebral disc. Arthritis Rheum.

This article is protected by copyright. All rights reserved 
58, 3798-808 (2008).

166. Merceron, C. et al. Loss of HIF-1 $\alpha$ in the notochord results in cell death and complete disappearance of the nucleus pulposus. PLoS One 9, e110768 (2014).

167. Gomes, A. P. et al. Declining NAD(+) induces a pseudohypoxic state disrupting nuclearmitochondrial communication during aging. Cell 155, 1624-38 (2013).

168. Welford, S. M. et al. HIF1alpha delays premature senescence through the activation of MIF. Genes Dev. 20, 3366-71 (2006).

169. Kilic Eren, M. \& Tabor, V. The role of hypoxia inducible factor-1 alpha in bypassing oncogeneinduced senescence. PLoS One 9, e101064 (2014).

170. Fujita, N. et al. Prolyl hydroxylase 3 (PHD3) modulates catabolic effects of tumor necrosis factor- $\alpha$ (TNF- $\alpha)$ on cells of the nucleus pulposus through co-activation of nuclear factor $\kappa B$ (NF-кB)/p65 signaling. J. Biol. Chem. 287, 39942-53 (2012).

171. Li, J. et al. Prolyl-4-hydroxylase domain protein 2 controls NF- $\kappa \mathrm{B} / \mathrm{p} 65$ transactivation and enhances the catabolic effects of inflammatory cytokines on cells of the nucleus pulposus. $J$. Biol. Chem. 290, 7195-207 (2015).

172. Blanco, J. F. et al. Isolation and characterization of mesenchymal stromal cells from human degenerated nucleus pulposus: comparison with bone marrow mesenchymal stromal cells from the same subjects. Spine (Phila. Pa. 1976). 35, 2259-65 (2010).

173. Feng, G. et al. Multipotential differentiation of human anulus fibrosus cells: an in vitro study. $J$. Bone Joint Surg. Am. 92, 675-85 (2010).

174. Risbud, M. V et al. Evidence for skeletal progenitor cells in the degenerate human intervertebral disc. Spine (Phila. Pa. 1976). 32, 2537-44 (2007).

175. Sakai, D. et al. Exhaustion of nucleus pulposus progenitor cells with ageing and degeneration of the intervertebral disc. Nat. Commun. 3, 1264 (2012).

176. Setton, L. a \& Chen, J. Mechanobiology of the intervertebral disc and relevance to disc degeneration. J. Bone Joint Surg. Am. 88 Suppl 2, 52-7 (2006).

177. Setton, L. A. \& Chen, J. Cell mechanics and mechanobiology in the intervertebral disc. Spine (Phila Pa 1976) 29, 2710-2723 (2004).

This article is protected by copyright. All rights reserved 
178. Chuang, S.-Y., Popovich, J. M., Lin, L.-C. \& Hedman, T. P. The effects of exogenous crosslinking on hydration and fluid flow in the intervertebral disc subjected to compressive creep loading and unloading. Spine (Phila. Pa. 1976). 35, E1362-E1366 (2010).

179. Wagner, D. R., Reiser, K. M. \& Lotz, J. C. Glycation increases human annulus fibrosus stiffness in both experimental measurements and theoretical predictions. J. Biomech. 39, 1021-1029 (2006).

180. Scharf, B. et al. Age-related carbonylation of fibrocartilage structural proteins drives tissue degenerative modification. Chem. Biol. 20, 922-934 (2013).

181. O’Connell, G. D., Vresilovic, E. J. \& Elliott, D. M. Human intervertebral disc internal strain in compression: the effect of disc region, loading position, and degeneration. J. Orthop. Res. 29, 547-55 (2011).

182. Osti, O. L., Vernon-Roberts, B., Moore, R. \& Fraser, R. D. Annular tears and disc degeneration in the lumbar spine. A post-mortem study of 135 discs. J. Bone Joint Surg. Br. 74, 678-682 (1992).

183. Cortes, D. H., Han, W. M., Smith, L. J. \& Elliott, D. M. Mechanical properties of the extrafibrillar matrix of human annulus fibrosus are location and age dependent. J. Orthop. Res. 31, 1725-1732 (2013).

184. Iatridis, J. C., Michalek, A. J., Purmessur, D. \& Korecki, C. L. Localized intervertebral disc injury leads to organ level changes in structure, cellularity, and biosynthesis. Cellular and Molecular Bioengineering 2, 437-447 (2009).

185. Cao, L., Guilak, F. \& Setton, L. A. Three-dimensional morphology of the pericellular matrix of intervertebral disc cells in the rat. J Anat 211, 444-452 (2007).

186. Cao, L., Guilak, F. \& Setton, L. A. Pericellular Matrix Mechanics in the Anulus Fibrosus Predicted by a Three-Dimensional Finite Element Model and In Situ Morphology. Cell. Mol. Bioeng. 2, 306-319 (2009).

187. Korecki, C. L., Kuo, C. K., Tuan, R. S. \& Iatridis, J. C. Intervertebral disc cell response to dynamic compression is age and frequency dependent. J. Orthop. Res. 27, 800-6 (2009).

188. Cho, H., Seth, A., Warmbold, J., Robertson, J. T. \& Hasty, K. A. Aging affects response to cyclic tensile stretch: Paradigm for intervertebral disc degeneration. Eur. Cells Mater. 22, 137146 (2011).

This article is protected by copyright. All rights reserved 
189. Sowa, G. A. et al. Cells from degenerative intervertebral discs demonstrate unfavorable responses to mechanical and inflammatory stimuli: a pilot study. Am. J. Phys. Med. Rehabil. 91, 846-55 (2012).

190. Stokes, I. A. F. \& Iatridis, J. C. Mechanical conditions that accelerate intervertebral disc degeneration: overload versus immobilization. Spine (Phila. Pa. 1976). 29, 2724-32 (2004).

191. Abumi, K. et al. Biomechanical evaluation of lumbar spinal stability after graded facetectomies. Spine (Phila. Pa. 1976). 15, 1142-7 (1990).

192. Urban, J. P. \& McMullin, J. F. Swelling pressure of the lumbar intervertebral discs: influence of age, spinal level, composition, and degeneration. Spine (Phila. Pa. 1976). 13, 179-87 (1988).

193. Iatridis, J. C., MacLean, J. J., O'Brien, M. \& Stokes, I. A. F. Measurements of proteoglycan and water content distribution in human lumbar intervertebral discs. Spine (Phila. Pa. 1976). 32, 1493-7 (2007).

194. Adams, M. A., McNally, D. S. \& Dolan, P. 'Stress' distributions inside intervertebral discs. The effects of age and degeneration. J. Bone Joint Surg. Br. 78, 965-72 (1996).

195. Krismer, M., Haid, C. \& Rabl, W. The contribution of anulus fibers to torque resistance. Spine (Phila. Pa. 1976). 21, 2551-7 (1996).

196. Michalek, A. J. \& Iatridis, J. C. Height and torsional stiffness are most sensitive to annular injury in large animal intervertebral discs. Spine J. 12, 425-432 (2012).

197. Yu, J., Fairbank, J. C. T., Roberts, S. \& Urban, J. P. G. The elastic fiber network of the anulus fibrosus of the normal and scoliotic human intervertebral disc. Spine (Phila. Pa. 1976). 30, 1815-20 (2005).

198. Iatridis, J. C., Mente, P. L., Stokes, I. A., Aronsson, D. D. \& Alini, M. Compression-induced changes in intervertebral disc properties in a rat tail model. Spine (Phila. Pa. 1976). 24, 9961002 (1999).

199. Hartman, R. A., Bell, K. M., Debski, R. E., Kang, J. D. \& Sowa, G. A. Novel ex-vivo mechanobiological intervertebral disc culture system. J. Biomech. 45, 382-5 (2012).

200. Muller-Lutz, A. et al. Age-dependency of glycosaminoglycan content in lumbar discs: A 3T gagCEST study. J. Magn. Reson. Imaging 10.1002/jmri.24945 (2015).

This article is protected by copyright. All rights reserved 
201. Iatridis, J. C., Setton, L. A., Weidenbaum, M. \& Mow., V. C. The viscoelastic behavior of the non-degenerate human lumbar nucleus pulposus in shear. J. Biomech. 30, 1005-1013 (1997).

202. Iatridis, J. C., Setton, L. A., Weidenbaum, M. \& Mow, V. C. Alterations in the mechanical behavior of the human lumbar nucleus pulposus with degeneration and aging. J Orthop Res 15, 318-322 (1997).

203. Acaroglu, E. R. et al. Degeneration and aging affect the tensile behavior of human lumbar anulus fibrosus. Spine (Phila. Pa. 1976). 20, 2690-2701 (1995).

204. Nasto, L. A. et al. Mitochondrial-derived reactive oxygen species (ROS) play a causal role in aging-related intervertebral disc degeneration. J. Orthop. Res. 31, 1150-1157 (2013).

205. Klawitter, M. et al. Curcuma DMSO extracts and curcumin exhibit an anti-inflammatory and anti-catabolic effect on human intervertebral disc cells, possibly by influencing TLR2 expression and JNK activity. J. Inflamm. 9, 29 (2012).

206. Ma, T. et al. The effect of curcumin on NF- $\kappa$ B expression in rat with lumbar intervertebral disc degeneration. Eur. Rev. Med. Pharmacol. Sci. 19, 1305-14 (2015).

207. Li, X. et al. The action of resveratrol, a phytoestrogen found in grapes, on the intervertebral disc. Spine (Phila. Pa. 1976). 33, 2586-95 (2008).

208. Krupkova, O. et al. Epigallocatechin 3-gallate suppresses interleukin-1 $\beta$-induced inflammatory responses in intervertebral disc cells in vitro and reduces radiculopathic pain in rats. Eur. Cell. Mater. 28, 372-86 (2014).

209. Horii, M. et al. Direct application of the tumor necrosis factor- $\alpha$ inhibitor, etanercept, into a punctured intervertebral disc decreases calcitonin gene-related peptide expression in rat dorsal root ganglion neurons. Spine (Phila. Pa. 1976). 36, E80-5 (2011).

210. Le Maitre, C. L., Freemont, A. J. \& Hoyland, J. A. A preliminary in vitro study into the use of IL-1Ra gene therapy for the inhibition of intervertebral disc degeneration. Int. J. Exp. Pathol. 87, 17-28 (2006).

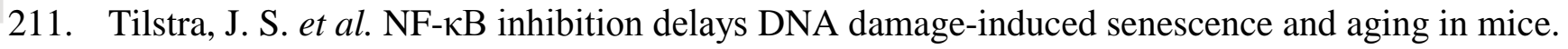
J. Clin. Invest. 122, 2601-12 (2012).

212. Okuma M; Miyamoto K; Chujo T; Kitahara S; \& Masuda. A new gene therapy approach: In

This article is protected by copyright. All rights reserved 
vivo transfection of "naked" NF-kB decoy oligonucleotide restored disc degeneration in the rabbit annular needle puncture model. in (Trans Orthopedic Research Society, 2005). at $<$ http://www.ors.org/Transactions/51/0045.pdf>.

213. Nishida, K. et al. Gene therapy approach for disc degeneration and associated spinal disorders. Eur. Spine J. 17 Suppl 4, 459-66 (2008).

214. Feng, C., Liu, H., Yang, Y., Huang, B. \& Zhou, Y. Growth and differentiation factor-5 contributes to the structural and functional maintenance of the intervertebral disc. Cell. Physiol. Biochem. 35, 1-16 (2015).

215. Mwale, F., Wang, H. T., Roughley, P., Antoniou, J. \& Haglund, L. Link N and mesenchymal stem cells can induce regeneration of the early degenerate intervertebral disc. Tissue Eng. Part A 20, 2942-9 (2014).

216. Leckie, S. K. et al. Injection of AAV2-BMP2 and AAV2-TIMP1 into the nucleus pulposus slows the course of intervertebral disc degeneration in an in vivo rabbit model. Spine J. 12, 7-20 (2012).

217. Clarke, L. E., Richardson, S. M. \& Hoyland, J. A. Harnessing the Potential of Mesenchymal Stem Cells for IVD Regeneration. Curr. Stem Cell Res. Ther. 10, 296-306 (2015).

218. Leckie, S. K. et al. Injection of human umbilical tissue-derived cells into the nucleus pulposus alters the course of intervertebral disc degeneration in vivo. Spine J. 13, 263-272 (2013).

219. Cho, H. et al. Snapshot of degenerative aging of porcine intervertebral disc: a model to unravel the molecular mechanisms. Exp. Mol. Med. 43, 334-40 (2011).

220. Busscher, I., Ploegmakers, J. J. W., Verkerke, G. J. \& Veldhuizen, A. G. Comparative anatomical dimensions of the complete human and porcine spine. Eur. Spine J. 19, 1104-14 (2010).

221. Shimizu, K. et al. Amyloid deposition in intervertebral discs of senescence-accelerated mouse. Arthritis Rheum. 25, 710-2 (1982).

222. Isaac, C. et al. Dystrophin and utrophin 'double knockout' dystrophic mice exhibit a spectrum of degenerative musculoskeletal abnormalities. J. Orthop. Res. 31, 343-9 (2013).

223. Bedore, J. et al. Impaired intervertebral disc development and premature disc degeneration in mice with notochord-specific deletion of CCN2. Arthritis Rheum. 65, 2634-44 (2013). 
224. Furukawa, T. et al. Absence of biglycan accelerates the degenerative process in mouse intervertebral disc. Spine (Phila. Pa. 1976). 34, E911-7 (2009).

225. Mason, R. M. \& Palfrey, A. J. Intervertebral disc degeneration in adult mice with hereditary kyphoscoliosis. J. Orthop. Res. 2, 333-8 (1984).

226. Semba, K. et al. A novel murine gene, Sickle tail, linked to the Danforth's short tail locus, is required for normal development of the intervertebral disc. Genetics 172, 445-56 (2006).

227. Paavola, L. G., Wilson, D. B. \& Center, E. M. Histochemistry of the developing notochord, perichordal sheath and vertebrae in Danforth's short-tail (sd) and normal C57BL/6 mice. $J$. Embryol. Exp. Morphol. 55, 227-45 (1980).

228. Holguin, N., Aguilar, R., Harland, R. A., Bomar, B. A. \& Silva, M. J. The aging mouse partially models the aging human spine: lumbar and coccygeal disc height, composition, mechanical properties, and Wnt signaling in young and old mice. J. Appl. Physiol. 116, 1551-60 (2014).

229. Silberberg, R. \& Gerritsen, G. Aging changes in intervertebral discs and spondylosis in Chinese hamsters. Diabetes 25, 477-83 (1976).

230. Laing, A. C., Cox, R., Tetzlaff, W. \& Oxland, T. Effects of advanced age on the morphometry and degenerative state of the cervical spine in a rat model. Anat. Rec. (Hoboken). 294, 1326-36 (2011).

231. Gruber, H. E., Gordon, B., Williams, C., Norton, H. J. \& Hanley, E. N. Vertebral endplate and disc changes in the aging sand rat lumbar spine: cross-sectional analyses of a large male and female population. Spine (Phila. Pa. 1976). 32, 2529-36 (2007).

232. Sowa, G. et al. Characterization of intervertebral disc aging: longitudinal analysis of a rabbit model by magnetic resonance imaging, histology, and gene expression. Spine (Phila. Pa. 1976). 33, 1821-8 (2008).

233. Bergknut, N. et al. The dog as an animal model for intervertebral disc degeneration? Spine (Phila. Pa. 1976). 37, 351-8 (2012).

234. Wade, K. R., Robertson, P. A. \& Broom, N. D. Influence of maturity on nucleus-endplate integration in the ovine lumbar spine. Eur. Spine J. 23, 732-44 (2014).

235. Stolworthy, D. K. et al. MRI evaluation of spontaneous intervertebral disc degeneration in the alpaca cervical spine. J. Orthop. Res. (2015). doi:10.1002/jor.22968 
236. Duncan, A. E., Colman, R. J. \& Kramer, P. A. Longitudinal study of radiographic spinal osteoarthritis in a macaque model. J. Orthop. Res. 29, 1152-60 (2011). 
Table 1: Animal models used to investigate age-associated intervertebral disc degeneration

\section{MOUSE MODELS}

Gene symbol Gene name/description

Erccl Excision repair cross-

complementing rodent repair 1

$n / a$

Senescence-accelerated mouse $(S A M)$

Dmd $^{M d x} \quad X$-chromosome-linked muscular

Dystrophy

Cnn2 Connective tissue growth factor

(CTGF or CCN2)

Bgn Biglycan

Ky Kyphoscoliosis peptidase

Skt Sickle tail

n/a Danforth's short tail locus (Sd)

C57Bl6

Wildtype mice

\section{Protein function}

DNA repair

Gene not yet identified

Dystrophin-skeletal muscle integrity

Matricellular protein involved in cellular adhesion, migration, ECM synthesis

Small leucine repeat proteoglycans ECM

Cytoskeleton-associated protease

required for normal muscle growth

Linked to Danforth's short tail locus

Gene not yet identified

Natural aging mice
Model

M

Derived from $\mathrm{AKR} / \mathrm{J}$

$\mathrm{M}$

TG

TG

ARM

TG

M, SD
Age-related disc degenerative changes

Systemic ERCCl-deficiency accelerated age-

dependent disc degeneration

Amyloid deposition in disc AF, articular cartilage

Age-related loss of disc proteoglycan

Notochord-specific CCN2 deletion accelerated age-dependent disc degeneration

Age-related early onset of disc degeneration

Degenerative changes in cervical and thoracic

discs; kyphosis

Abnormal development of the intervertebral

disc

Aberrant patterns of vertebrae and disc

development

Natural aging-related disc degeneration
Ref

Genetic models: Mutation (M), Transgenic (TG), Autosomal recessive mutation (ARM), Truncation mutation (TM). N/A: not applicable.

\section{OTHER ANIMAL MODELS}

\begin{tabular}{|c|c|c|c|c|}
\hline Animals & Scientific name & Key features \& analysis methods & Age-related disc degenerative changes & Ref \\
\hline Hamster & Cricetinae & $\begin{array}{l}\text { Chinese hamsters prone to development of spontaneous diabetes. } \\
\text { Spines of age 10-33 months histologically analyzed }\end{array}$ & $\begin{array}{l}\text { Aging changes in intervertebral discs. } \\
\text { Spondylosis was present at an earlier age in } \\
\text { diabetic than in nondiabetic hamster }\end{array}$ & 229 \\
\hline Rat & Rattus & Male Fisher 344 rats. $\mu \mathrm{CT}$ of spines of age $3,12,18,30$ months & $\begin{array}{l}\text { Age-associated morphometric and } \\
\text { degenerative disc changes }\end{array}$ & 230 \\
\hline Sand rat & Psammomys obesus & $\begin{array}{l}\text { Spontaneous development of diabetes. Age 1-46 months analyzed } \\
\text { radiographically and histologically }\end{array}$ & $\begin{array}{l}\text { Age-related and diabetes-related spontaneous } \\
\text { development of lumbar disc degeneration }\end{array}$ & 231 \\
\hline Pig & Sus scrofa domesticus & Porcine discs of age 2-3weeks, 6-9 month, 2-3 years analyzed by & $\begin{array}{l}\text { Disc MMP-1 increased with age. GAG and } \\
\text { collagen I, II, aggrecan decreased with age. }\end{array}$ & 219 \\
\hline
\end{tabular}

This article is protected by copyright. All rights reserved 
histology, GAG assay, cell density assay, gene expression.

Discs of chondrodystrophic (CD) and nonchondrodystrophic (NCD) dogs of age 1-7 years were analyzed by histology, GAG, and MMP activity

CD dogs showed early age onset of disc degenerative changes compared to NDC dogs.

Discs of new-born, 3,12 , and $>36$ months were analyzed mechanically and microscopically to assess nucleus pulposusendplate integration

Young (2-6 years) and older (>10 years) alpaca underwent MRI evaluation to detect cervical spine degeneration

Longitudinal study of macques 11-32 years of age to assess disc space narrowing (DSN) by radiography.
Rapid increase in NP-EP insertion nodes between birth and 3 months, after which this integration remained constant.

No cervical disc degeneration in young

alpacas. Increased disc degeneration incidence and severity at lower cervical levels in older alpacas

Age-associated disc space narrowing, osteophytosis, increased disc tissue stiffness
(Macaques monkeys)
Macaques

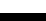

This article is protected by copyright. All rights reserved 
Young
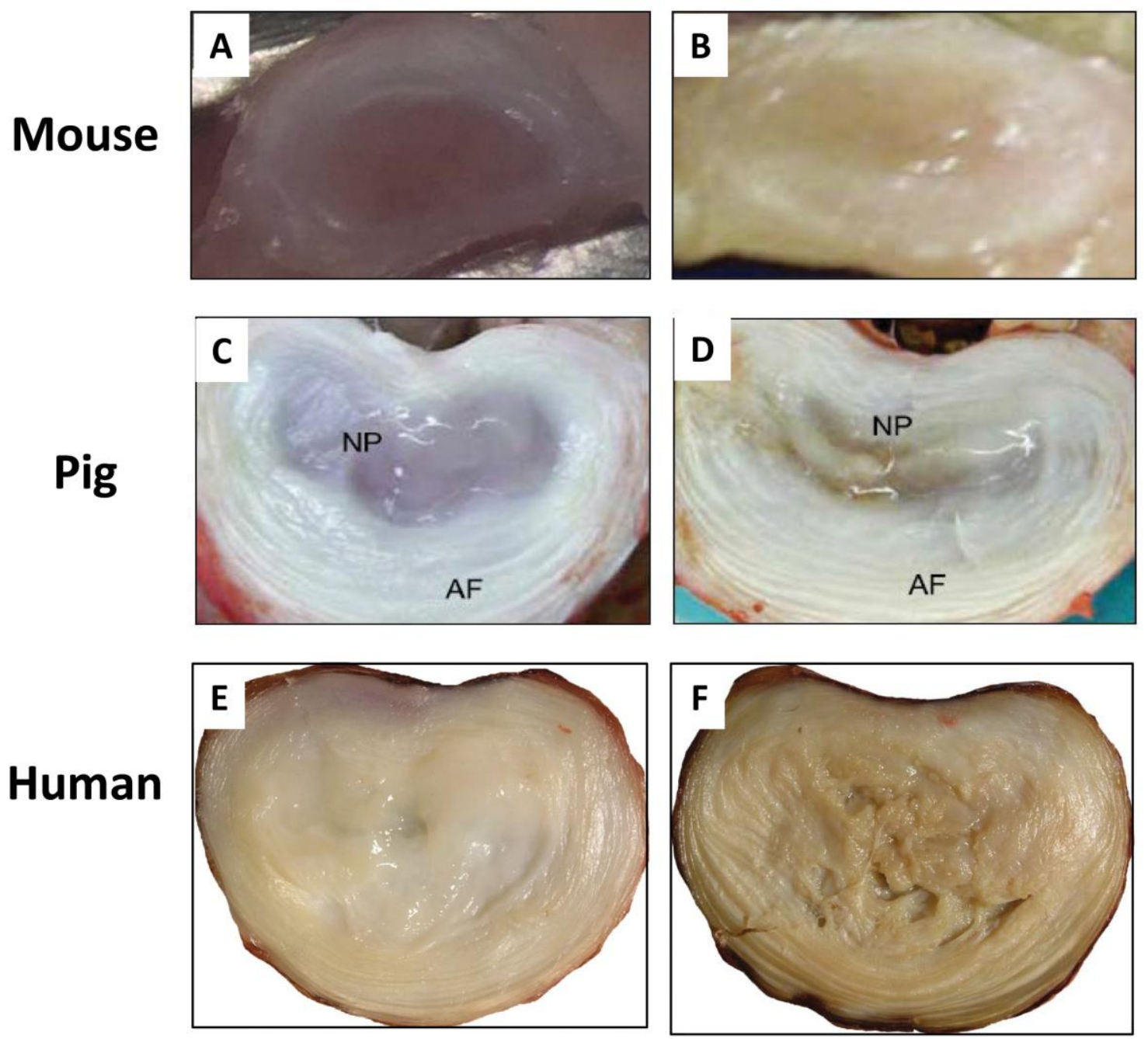

Figure 1 


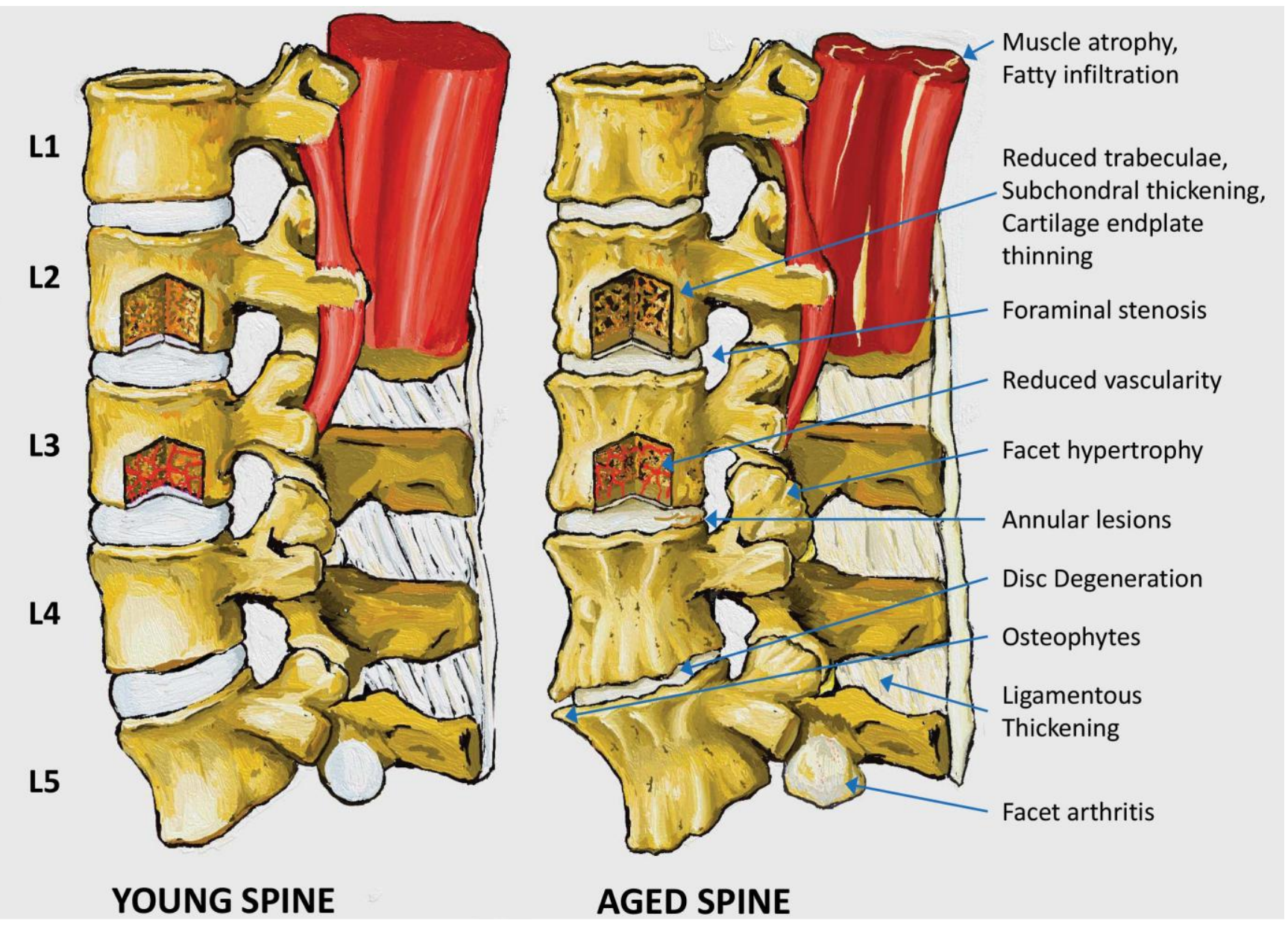

Figure 2

This article is protected by copyright. All rights reserved 


\section{A DISC AGING BIOCHEMICAL CASCADE}

B THERAPUETIC TARGETS \& STRATEGIES

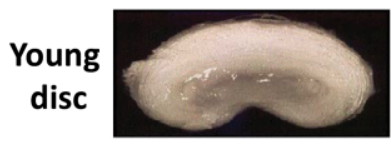

\section{Exogenous stressors}

- Physical (load)

- Chemical (smoking)

- UV/IR radiation

- Injury

\section{Endogenous stressors}

- DNA replication errors

- Metabolic (oxidants, ROS)

- Hyper-osmolality

- Inflammation

4

Phase I: Biomolecular damage

- Genomic instability

- Loss of proteostasis (ECM degradation)

- Epigenetic alterations *<smiles>C1CC2CCC1C2</smiles>

Phase II: Aberrant responses to damage

- Dysregulated signaling (MAPK, NF-кB)

- Abnormal cellular changes

Cellular senescence

Apoptosis

Aberrant cellular response (load, stress)

- Dysregulated nutrient sensing *

- Mitochondrial dysfunction *

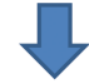

Phase III: Loss of biologic structure \& function

- Loss of disc matrix integrity

- Loss of disc functional cells

- Stem cell exhaustion

- Loss of disc biomechanics

- Altered ECM-cell communication *

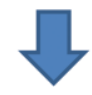

INTERVERTEBRAL DISC AGING

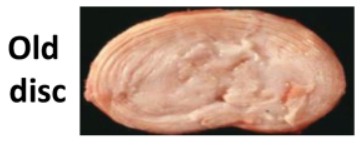

Gene therapy (ECM restoration)

Anti-catabolic agents (TIMPs)

Link $\mathbf{N}$ peptide

NF-KB inhibitor

Senolytic agents, SASP blockers

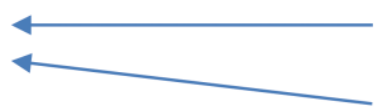

Matrix therapy (ECM restoration)

Cell therapy (functional cell restoration)

\section{Figure 3}

This article is protected by copyright. All rights reserved 


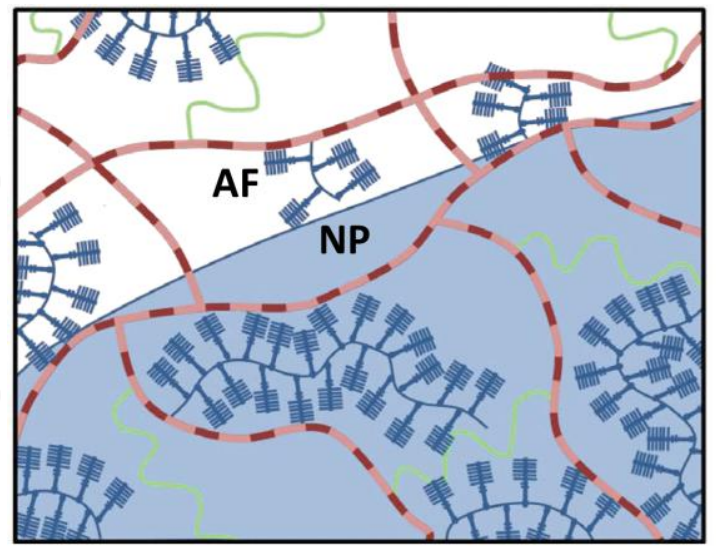

YOUNG MATRIX

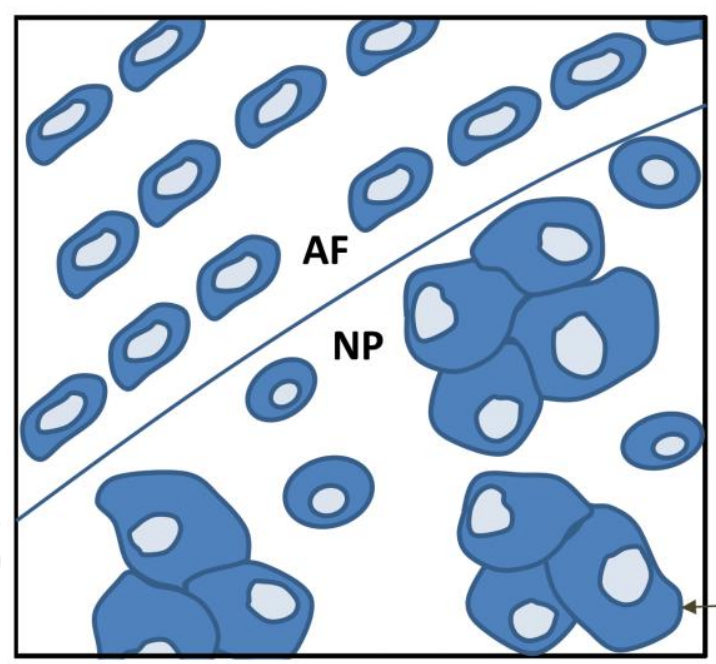

YOUNG CELLS

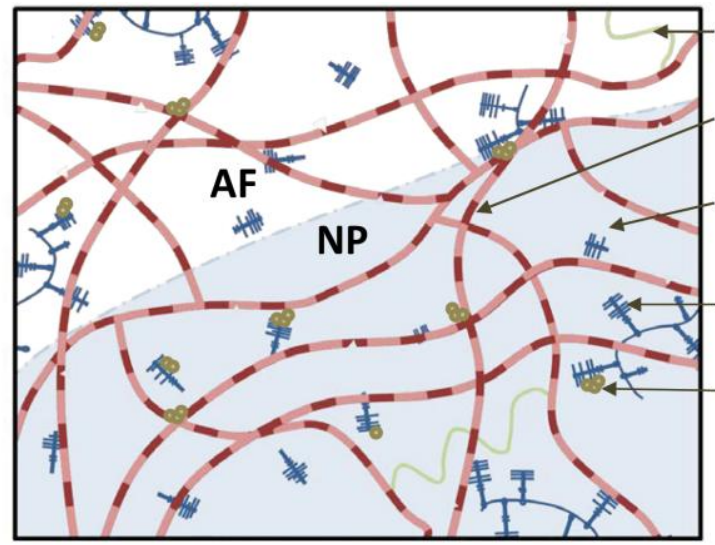

AGED MATRIX

Elastin loss

Increased collagen \& collagen crosslinking Aggrecan

fragmentation

Diminished aggrecan \& GAG

AGE

NP hydration loss

(A)

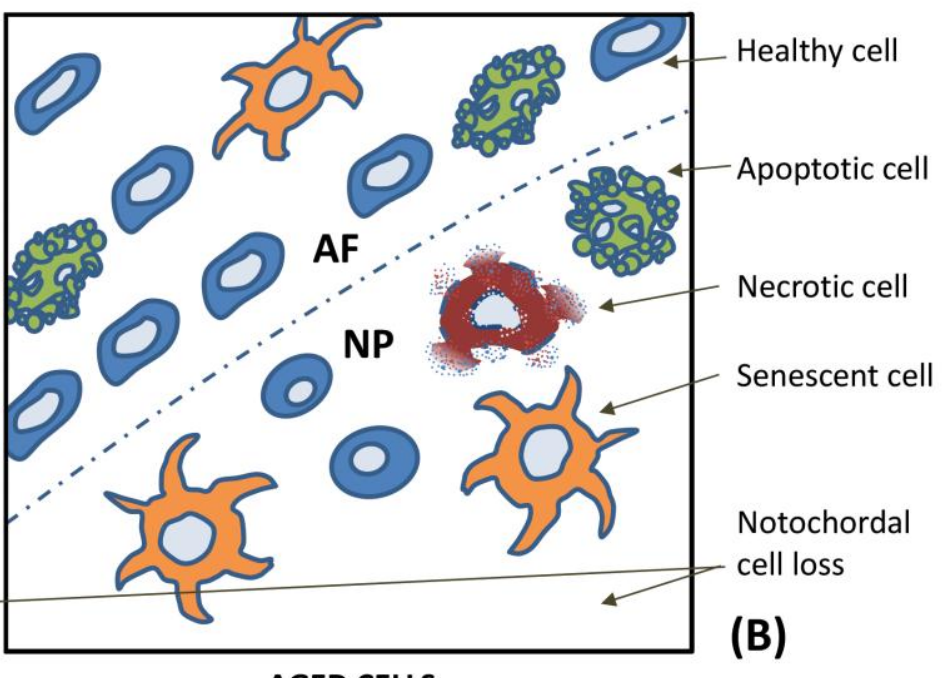

Figure 4 